\title{
The fossil lagerstätte Sandelzhausen (Miocene; southern Germany): history of investigation, geology, fauna, and age
}

\author{
Markus Moser • Gertrud E. Rössner • \\ Ursula B. Göhlich · Madelaine Böhme • \\ Volker Fahlbusch
}

Received: 6 May 2008/Accepted: 29 August 2008/Published online: 7 February 2009

(C) Springer-Verlag 2009

\section{Introduction}

The Miocene fossil lagerstätte Sandelzhausen in southern Germany ranks among the most important Neogene fossil terrestrial localities in Europe, due to its exceptional record of both macro- and microvertebrates as well as invertebrates. From its discovery in 1959 until its final closure in 2001, the site has been the subject of two long-term, systematic digging campaigns (1969-1975 and 1994-2001) as well as occasional collecting by the Ludwig-MaximiliansUniversität (LMU) together with the Bayerische Staatssammlung für Paläontologie und Geologie (BSPG; both Munich). In addition to a few plant remains a fossil fauna comprising more than 200 taxa and 50,000 identifiable specimens (Fahlbusch 2003, and this paper Table 1) has been collected including ostracods, molluscs, and, especially, vertebrates of all groups, with an emphasis on

\section{Fahlbusch: deceased.}

M. Moser $(\varangle)$ · G. E. Rössner

Bayerische Staatssammlung für Paläontologie und Geologie,

Richard-Wagner-Strasse 10, 80333 Munich, Germany

e-mail: dml_moser@web.de

G. E. Rössner

e-mail: g.roessner@1rz.uni-muenchen.de

U. B. Göhlich

Geological-Paleontological Department,

Natural History Museum of Vienna, Burgring 7,

1010 Vienna, Austria

e-mail: ursula.goehlich@nhm-wien.ac.at

M. Böhme · V. Fahlbusch

Sektion Paläontologie, Department für Geo- und

Umweltwissenschaften, Ludwig Maximilians Universität

München, Richard-Wagner-Strasse 10, 80333 Munich, Germany

e-mail: m.boehme@1rz.uni-muenchen.de mammals (all material housed in BSPG, Munich). Though the vertebrate remains are almost exclusively disarticulated, they represent a variety of both autochthonous and allochthonous environments and they document extensive series of ontogenetic stages and within-species variability. Scientific results derived from Sandelzhausen have been published since 1970 and, ultimately, 26 specialists involved in Sandelzhausen research came together in September 2005 at the Sandelzhausen Symposium in Mainburg to discuss the latest results on all faunistic, ecological, and genetic aspects of the fossil site (Fig. 5a, b; Anonymous 2005, Rössner 2006a, Rössner and Fahlbusch 2006). The present volume resulted from that meeting and presents new contributions to the fossil fauna of Sandelzhausen. The purpose of this paper is to give a short overview and a summary of previous work on the Sandelzhausen fossil site, to document the fieldwork and the geological context, and to discuss the age of the fauna. A German-language summary article including the most recent faunal list, details of the excavation, and the complete publication list up to 2002, including popular accounts (e.g., Fahlbusch and Liebreich 1996), can be found in Fahlbusch (2003). A partly synthetic paper on the genesis and ecology of the site compiling all available research results and new evidence about the fossil lagerstätte will be published elsewhere (in preparation).

\section{Geological and geographical setting}

The fossil site of Sandelzhausen near Mainburg, $60 \mathrm{~km}$ north of Munich (München) (Fig. 1) ( $\mathrm{R}^{44} 85$ 540-610, $\mathrm{H}^{53}$ 87 680-720 Gradabteilungsblatt 7336 Mainburg, 1:25 000, Bayerisches Landesvermessungsamt München 1959; GPS $48^{\circ} 37^{\prime} 36.9^{\prime \prime}, 11^{\circ} 48^{\prime} 11.6^{\prime \prime}$; $493 \mathrm{~m}$ height above sea level) is located within the Molasse Basin, the subsiding North 
Table 1 Number of taxa and references for Sandelzhausen fossil groups

\begin{tabular}{|c|c|c|}
\hline Group & $\begin{array}{l}\text { Minimum number } \\
\text { of taxa }\end{array}$ & References \\
\hline Plantae & 3 & $\begin{array}{l}\text { Jung in Fahlbusch and Gall (1970); Gregor (1982a, b); Gregor } \\
\text { et al. (1989); Jung (1996) }\end{array}$ \\
\hline Ostracoda & 14 & Witt (1998) \\
\hline Mollusca & 69 & Gall $(1972,1973)$; Moser et al. (2009 this volume) \\
\hline Teleostei & 4 & Böhme (1999b; 2009) \\
\hline Amphibia & 12 & Böhme (1999b; 2009) \\
\hline Reptilia & 29 & $\begin{array}{l}\text { Scherer }(1973,1981) \text {; Schleich }(1981,1983,1984) \text {; Böhme } \\
\quad \text { (1999a, b, 2009); Szyndlar (2009 this volume) }\end{array}$ \\
\hline Aves & 14 & Göhlich $(2002,2003)$ \\
\hline Marsupialia & 1 & Ziegler (2000) \\
\hline Lipotyphla & 17 & Ziegler $(1999,2000)$ \\
\hline Chiroptera & 2 & Ziegler (2000) \\
\hline Carnivora & 9 & Morlo et al. (2004); Nagel et al. (2009 this volume) \\
\hline Rodentia & 18 & $\begin{array}{l}\text { Fahlbusch (1964, 1975); Mayr (1979); Heissig (1997); Daams } \\
\text { et al. (1999); Hugueney (1999); Kälin (1999); Rummel } \\
\text { (1999); Ziegler (2005); Bruijn (2009 this volume); Stefen } \\
\text { (2009 this volume); Wessels and Reumer (2009 this volume) }\end{array}$ \\
\hline Lagomorpha & 3 & Fahlbusch et al. (1974), Angelone (2009 this volume) \\
\hline Pholidota & 1 & Fahlbusch (1998), Koenigswald (1999) \\
\hline Perissodactyla & 5 & $\begin{array}{l}\text { Heissig (1972, 1999); Abusch-Siewert (1983); Yan and Heissig } \\
\text { (1986); Peter (1999, 2002); Coombs (2009 this volume); } \\
\text { Kaiser (2009 this volume); Schulz and Fahlke (2009 this } \\
\text { volume); Tütken and Vennemann (2009 this volume) }\end{array}$ \\
\hline Artiodactyla & 7 & $\begin{array}{l}\text { Schmidt-Kittler (1971); Fahlbusch (1977); Köhler (1993); } \\
\text { Rössner (1997, 2002, 2004, 2009); Gentry et al. (1999); } \\
\text { Kaiser and Rössner (2007); Kaiser (2009 this volume); Made } \\
\text { (2009 this volume); Tütken and Vennemann (2009 this } \\
\text { volume) }\end{array}$ \\
\hline Proboscidea & 2 & $\begin{array}{l}\text { Schmidt-Kittler (1972); Göhlich (1998, 1999, 2009); Tütken } \\
\text { and Vennemann (2009 this volume); Calandra et al. (2009) }\end{array}$ \\
\hline Total fauna & 210 & $\begin{array}{l}\text { Fahlbusch and Gall (1970); Fahlbusch et al. (1974); Fahlbusch } \\
\text { (1976b); Fahlbusch (2003); Moser et al. (this paper) }\end{array}$ \\
\hline
\end{tabular}

Alpine Foreland Basin which received sediment load mainly from the Alps (Lemcke 1988, Schwerd et al. 1996: $142 \mathrm{ff})$. At the beginning of the Miocene, this originally marine marginal basin of the Paratethys, itself a Cenozoic side arm of the Tethys (Kováč et al. 2007), became a relic basin as the Paratethys continuously retreated eastwards. The nonmarine younger Molasse deposits from late Early Miocene (Early Karpatian) to early Late Miocene (Early Pannonian), the so-called Upper Freshwater Molasse (Obere Süßwassermolasse, or OSM), document the final filling up of the basin under freshwater conditions (Doppler 1989; Doppler et al. 2000). During that time, the retreating sea level gave rise to what became predominantly a wetland with a mosaic of marshes, fens, peatlands, forests, and with permanent and temporary water bodies such as ponds and braided rivers, all draining westwards. This palaeoenvironmental setting is shown conclusively by the sedimentological record (Lemcke et al. 1953; Blissenbach 1957; Unger 1989; Schmid 2002; Seehuber 2002) as well as by ecological inference derived from the fossil record of plants, invertebrates, and vertebrates (e.g., Fahlbusch et al. 1974; Gregor 1982a; Schwarz and Reichenbacher 1989; Sach 1999; Göhlich 2002; Böhme 2003; Böhme and Reichenbacher 2003; Sach et al. 2003; Reichenbacher et al.

Fig. 1 Location and lithology of the Sandelzhausen fossil lagerstätte. In the aerial photo, the position of the areas of systematic excavations west and east of the Prof.-Dehm-Straße are indicated by black outlines. The eastern area was exploited 1996-1998, while the western part was exploited both in the campaigns of 1969-1975 and 1994-2001 (for a detailed plan of grid squares with the years of excavation see Fahlbusch 2003). Not indicated are sporadic diggings from 1959 until 1968, and in 1996 (see text for history). Triangles and circles show the position of selected profiles and logs, respectively, which are represented schematically below by small lithological columns (horizontally normalized to the "coal layer"). The larger column (right) shows lithological details and the subdivision into layers $A-D$ for the profile at grid square meter $10 \mathrm{G}$, which was sampled in 5-cm intervals in 1969 (see also Moser et al. 2009 this volume). The subdivision into layers had been coined already in 1966 and was retained as being useful ever since (photo of test profile in lower left corner, photo by V.F.) 


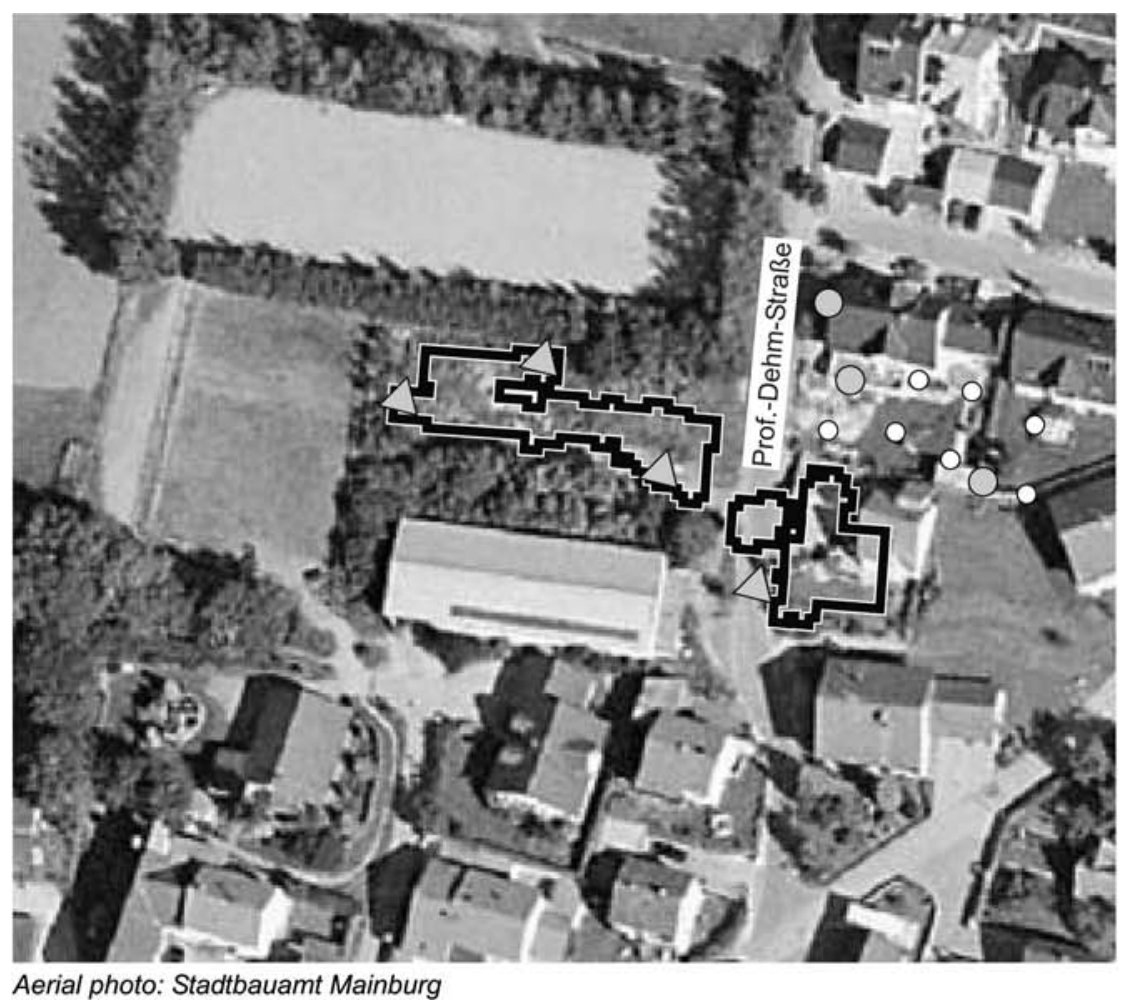

profiles $(\backslash$ and logs $(\bigcirc)$
(logs not shown below:O)

from West to East:
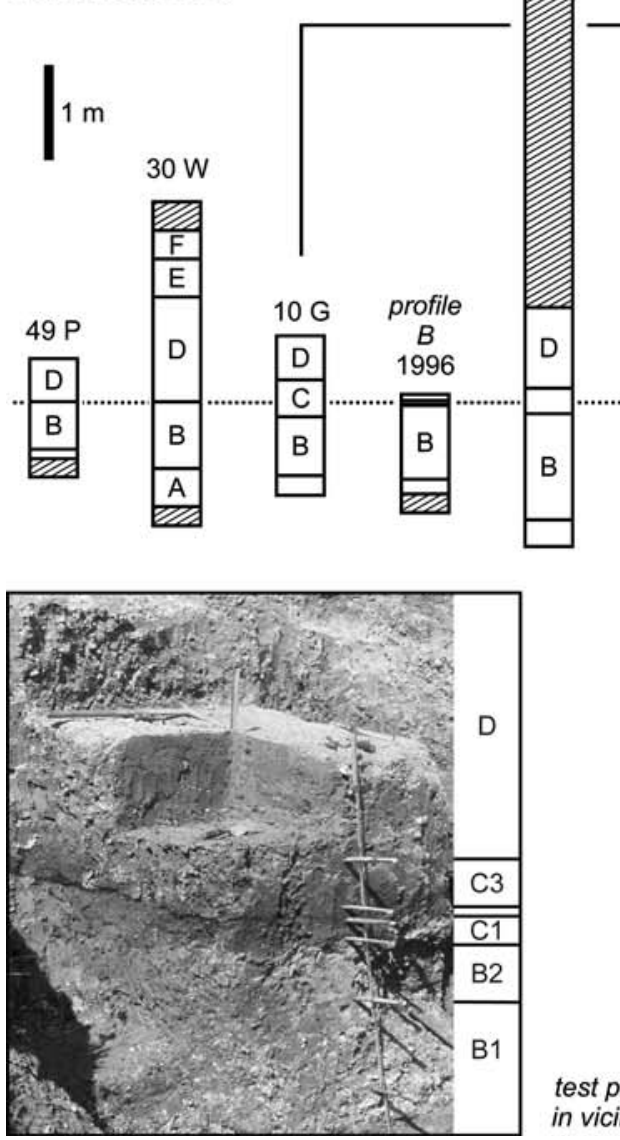

$\log 10$

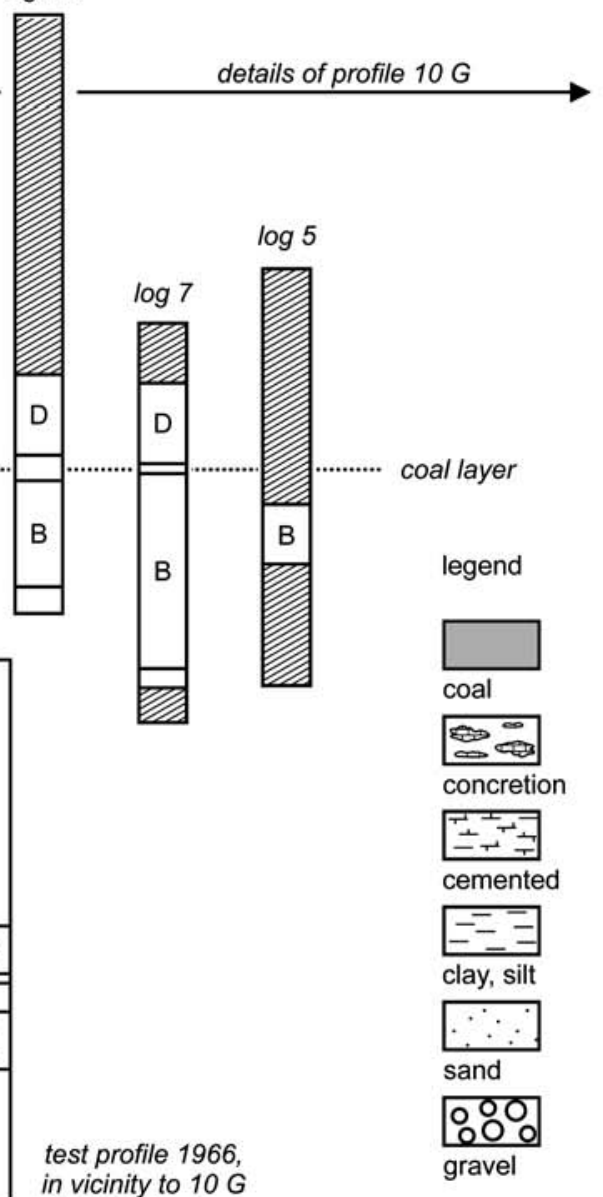

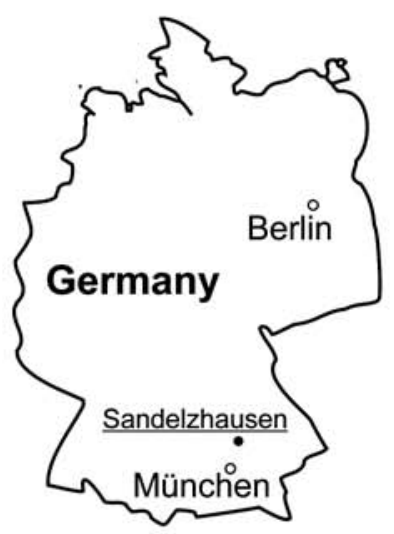

\section{150
140}

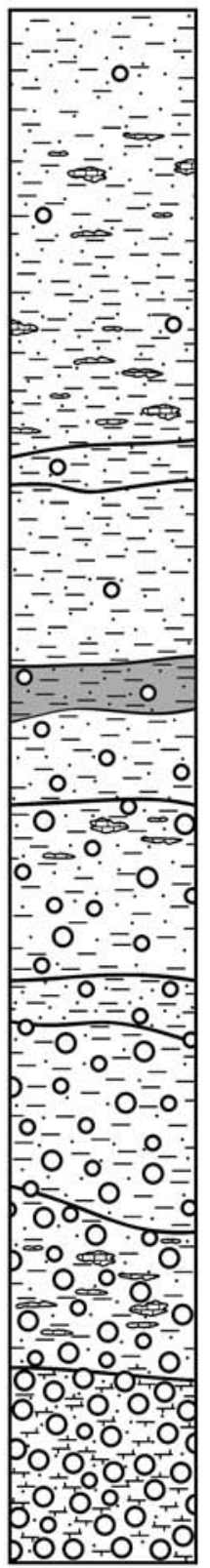



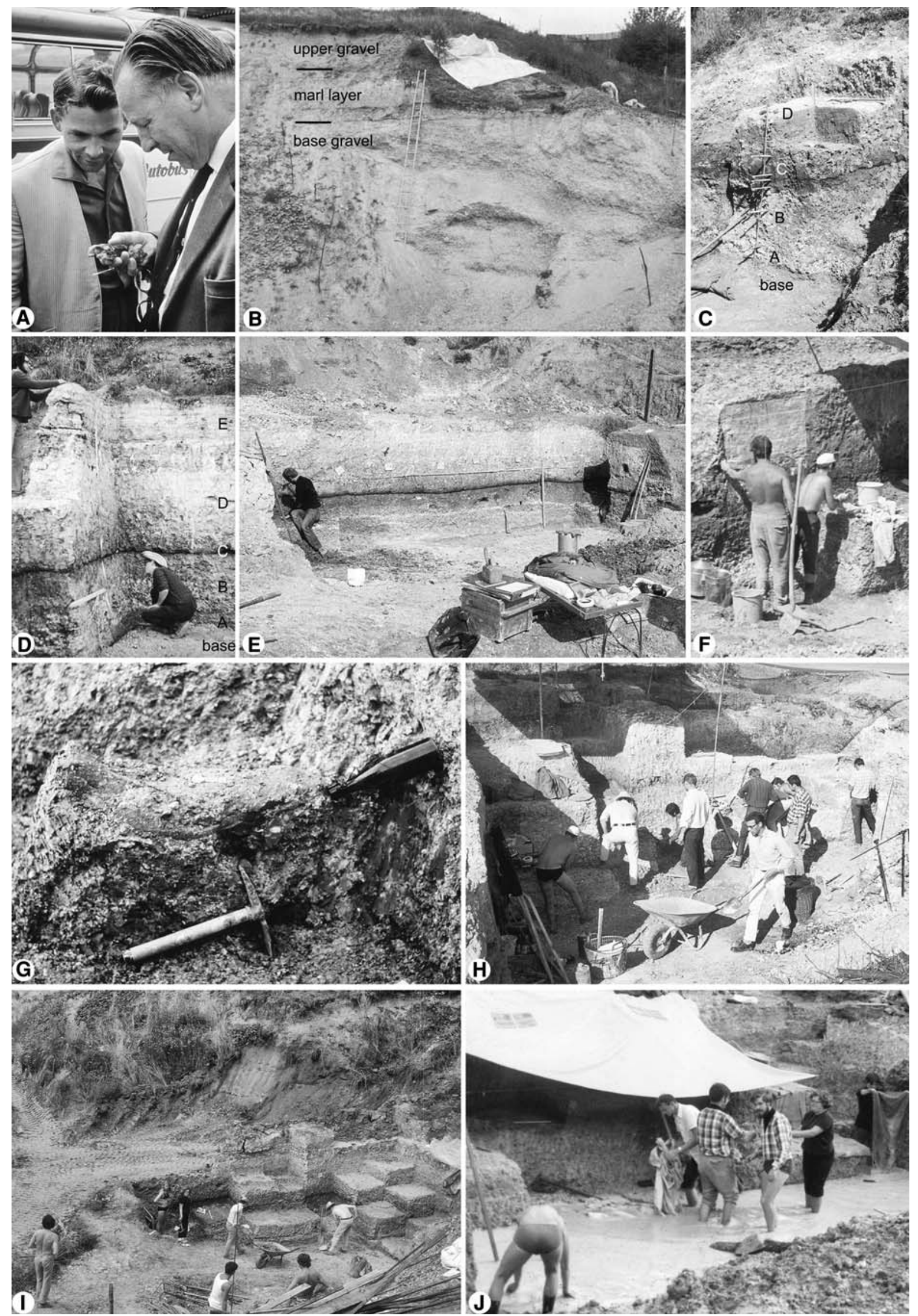
\ig. 2 Sandelzhausen field photos 1963-1975 (all photos by V.F., except where noted). a Occasional find of vertebrate remains during an institutional trip in July 1963. Richard Dehm with his graduate student Volker Fahlbusch. Photo by Herbert Hagn. b View of the north side of the gravel pit in May 1964. Afterwards, the pit was abandoned and partly refilled. The fossiliferous marl layer is situated in the upper third of a gravel package termed "Nördlicher Vollschotter." c First systematic investigation of the profile for its fossil distribution and sedimentology in May 1966. Definition of the layers $A, B, C, D$ with sublayers $B 1, B 2, C 1, C 2$, and $C 3$ (see Fahlbusch and Gall 1970). d Nearly complete vertical section with layers $A-E$. August 1972. e An E-W section exposed at the end of the excavation period in September 1973 showing continuously developed layers. This is typical for most of the western part of the Sandelzhausen site, but not for the eastern part excavated during the 1990s, where the thickness of layers is more variable. f Preserving a vertical section by gluing and transferring the sediment in situ onto fabric in August 1970. Several of these sections are housed in the BSPG and one is on exhibit in the City Museum of Mainburg. g First complete skull find: the rhinocerotid "Karl-Otto." October 1970. Photo by M. Kindl. h Systematic excavation in September 1970. The area is divided by a grid of north-oriented square meters, each of which was worked on one by one down to the base. Photo by Wolf-Dieter Grimm. i Systematic excavation in August 1972. The upper parts of the marl layer had been removed, as they were thought to be barren of vertebrate remains at that time. $\mathbf{j}$ A frequently recurring problem during all excavation periods was the complete watering of the excavation site by strong rain events. August 1970

2004; Rössner 2004; Heissig 2006; Reichenbacher and Prieto 2006; Rössner 2006b; Eronen and Rössner 2007).

Plants are rarely preserved in most vertebrate-rich localities (e.g., Sandelzhausen), however, a rich palaeobotanical fossil record in favorable localities shows that, besides an azonal vegetation surrounding the water areas, the hinterland was composed of evergreen to deciduous zonal forests and woodlands with legumes, indicating humid subtropical to warm temperate climatic conditions containing forests (Schmidt 1976, 1980; Gregor 1982a, b; Schmid and Gregor 1983; Gregor et al. 1989; Spitzlberger 1989; Selmeier 1989; Riederle and Gregor 1997; Schweigert 1992; Jechorek and Kovar-Eder 2004; Böhme et al. 2007).

The Sandelzhausen fossil section is embedded within gravel beds termed "Nördlicher Vollschotter," which constitutes a member of the OSM deposits (Doppler 1989: Table 1; Abdul Aziz et al. 2008: Fig. 2). The section is up to $3 \mathrm{~m}$ thick and built up mainly by marls with pebbles (for details see Fahlbusch et al. 1972, and below).

\section{History of investigation}

The fossil-rich 2-3-m-thick marl layer of Sandelzhausen was discovered by Richard Dehm in 1959, during a weekend family trip to a gravel pit, at that time still in use. On the spot he found gastropod shells, turtle bones, and a rhinocerotid jaw, as well as micromammals. Occasional collecting in the following years and campaigns for microfossil bulk sampling in 1962 and 1963 yielded sediment containing molluscs and micromammals well suited for screen washing. Further investigations in 1964 found that disarticulated remains of larger mammals were also rather abundantly present and this discovery resulted in several smaller digging campaigns in 1964-1968 and finally in a larger long-term digging campaign from 1969 till 1975. During the latter campaign systematic excavations based on a square meter grid ("Planquadrate", PQ) (Fig. 2h, i; see Fahlbusch et al. 1974; Fahlbusch 2003) and distinct lithological horizons (see Fahlbusch and Gall 1970; Fahlbusch et al. 1974; this paper below and Fig. 1) allowed recording of the exact position within the fossil site for a large portion of the recovered fossils and even the orientation for the larger fossils. The sections derived during these early years were fairly uniform with respect to sedimentology and distribution of fossil content, showing only a small amount of lateral variation, though already a concentration of fossils in the eastern area of the site along a NW-SE axis was noted.

After 1975, the remaining site was used agronomically until 1994, when the City of Mainburg bought the ground and offered the opportunity for further investigations. During the second extensive field campaign period from 1994 to 2001 (Figs. 3 and 4), the eastern natural border of the fossil site was found and an area continuous with the earlier observed NW-SE axis was found to be extraordinarily rich in larger mammal fossils (Fig. 4a-f). Additionally, a core drilling program with the help of the Bayerisches Geologisches Landesamt (Bavarian Geological Survey) was initiated to find the distance to which the fossil site extended northeast and east (Fig. 4h; see log positions in Fig. 1). Westwards, the marly layer can be traced for at least $1 \mathrm{~km}$, but diminishes both in thickness and grain size as well as in fossil richness. In 2002, the last remaining excavation cavity of the fossil site was filled in and is planned to be covered with buildings in the near future. However, towards the north and west, the fossiliferous layer is still available, though covered by several meters of younger deposits, and the area is still agronomically used. The street Prof.-Dehm-Straße and two information panels (Fig. 5c, d) for the public recall the fossil site and its contribution to the knowledge of the fauna and the palaeoenvironment 16 million years ago.

\section{Lithology (Fig. 1)}

The initial subdivision from 1966 of the marly horizon into layers A-D, later supplemented by layers E-F (Fahlbusch and Gall 1970; Fahlbusch et al. 1972, 1974; Fahlbusch 2003), has been applied during all investigations of the site. However, several marker horizons used initially proved 

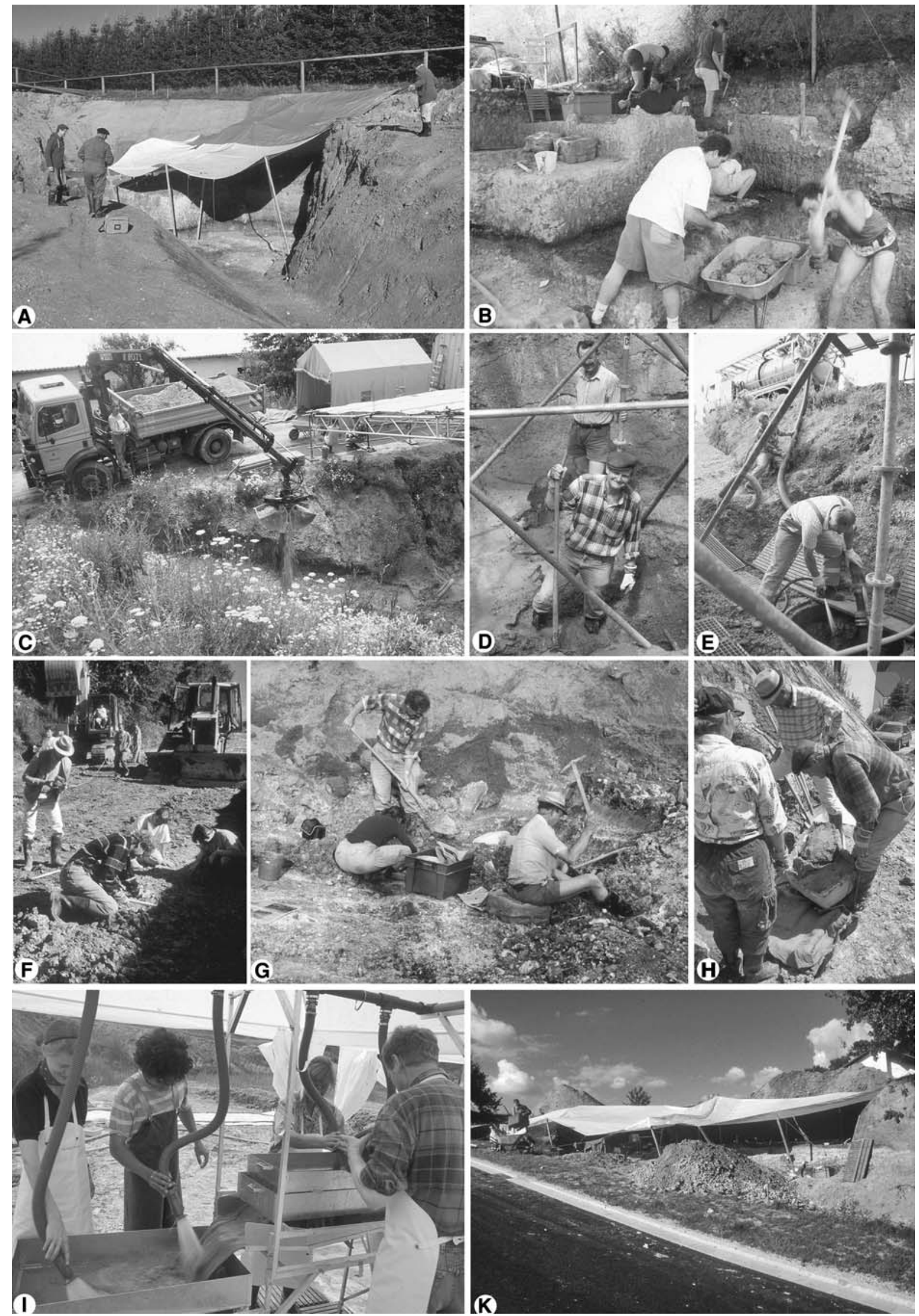
Fig. 3 Sandelzhausen field photos 1994-1997 (all photos by M.M.). a W. Werner, V. Fahlbusch, and R. Liebreich at the western digging site (end of season 1994). b Typical arrangement of work: the fossiliferous horizon was worked on with small picks and knives while the cemented base of some areas had to be removed with a large pick-axe. Fossils were referred to the field bureau (1995). c Workers of the City of Mainburg frequently removed the ever-growing excavation debris (picture 1996). d, e Repeatedly, heavy rainfalls flooded the pit with mud (picture 1996 with W. Werner and K. Heissig). Therefore, the City of Mainburg built a drainage system and kept it clean (picture 1996). f-h In 1996, during work for the new street (later called Prof.-Dehm-Straße) fossils had to be picked at great speed without position data. f Early morning. $\mathbf{g}$ Late evening. $\mathbf{h}$ A rhino skull in plaster package ready for transport (W. Werner, K. Heissig, R. Liebreich). i Screen washing for microfossils was undertaken usually once a week (picture 1997). k New site east of the newly built Prof.-Dehm-Straße in 1997

either not to hold throughout all sections (e.g., the "coal layer" and several sandy or pebbly layers) or to be otherwise unreliable (pedogenetic carbonate nodules and cements, diagenetic colouration, partial decarbonatization, and minor cryoturbation). Detailed investigations of the sedimentology and taphonomy were conducted by $\mathrm{Fa}$ hlbusch and Gall (1970); Herold and Ibrahim (1972); Fahlbusch et al. (1972, 1974), and finally Schmid (2002), who also dealt with the pedogenesis. Additional details will be published elsewhere (in preparation). The fossil-rich layers $\mathrm{B}$ and $\mathrm{C}$ have been exploited consistently, while higher parts of layer D and above could be examined only during the second digging period (1994-2001).

- Layer A (thickness 0-25 cm, usually $15 \mathrm{~cm}$ )

The basal layer A consists of marly, coarse gravels, overall brownish, in some areas heavily cemented by pedogenetic carbonates, resulting in a solid conglomerate which rather hampers proper preservation. The rare fossil content shows signs of transport and is mostly limited to robust fragments such as proboscidean tusks and cheek teeth.

- Layer B (thickness 40-120 cm, accelerating northeastwards)

The mostly greenish (in places yellowish) layer B (initially subdivided using various bands of pedogenetic carbonate nodules and colour differences), consists roughly of a fining upward sequence of gravel-rich marls, in which both size and number of pebbles diminish upwards. In detailed investigation, intercalated sand horizons and repeated fining upward subsequences provide evidence for nonuniform, discontinuous sedimentation. Layer B yielded most of the macrovertebrate remains and is rich in carbonate nodules $(\sim 30 \%)$.

- Layer C (thickness 0-40 cm)

The dark-brownish, almost black, organic rich layer ("coal layer" or C2) in the middle of the fossiliferous horizon is the most easily recognizable marker (up to $\sim 10 \mathrm{~cm}$ thick) in the section (e.g., Fig. 3g). Above (C3) and below ( $\mathrm{C} 1)$, the sediment is coloured dark-brownish or violet. This color pattern is present even in areas where the dark organic-rich horizon is lacking. The dark organic-rich layer consists of weakly coalified plant debris (recognizable as wood fragments and twigs), abundant mollusc shells (some even preserving color pattern), and the marly sediment. Towards the marker horizon, gravel size diminishes to very fine gravel and coarse sand. Above the marker bed, gravel content is present, but is greatly reduced. Layer $\mathrm{C}$ is further characterized by the complete lack of any pedogenetic carbonate nodules or cementations and by the highest fossil concentration, though the fossil material is strongly compacted.

- Layer D (thickness $\sim 100 \mathrm{~cm}$ )

The light-greenish to grey marls (mainly silt) contain few pebbles, but a significant proportion of diffuse carbonate and carbonate nodules (subhydrous pedogenesis) especially in the lower part. Larger fossils often show signs of reworking or long transport. However, though rare, some of the best preserved specimens come from this horizon due to a less intensive compaction.

- Layer E (thickness $\sim 10 \mathrm{~cm}$ )

Dark-greenish silty clays. These were originally thought to be free of fossils, but are now known to contain microvertebrates (Böhme 2009).

- Layer F (thickness $\sim 30 \mathrm{~cm}$ )

The base consists of a few-centimetres-thick laminite containing up to 17 bands with alternating light and dark color (Böhme 2009 this volume), locally containing whitish carbonate concretions and polygonal patterns of desiccation cracks. Above this follows greenish-yellowish clays. No fossils are found.

\section{Fauna}

Summarizing previous investigations from 1959 until 1969, including the first systematic digging season in 1969, Fahlbusch and Gall (1970) already noted that Sandelzhausen "...is the richest fossil vertebrate collecting site of the OSM of Bavaria found in decades-if not at all" (translated). The fossil list provided by Fahlbusch and Gall (1970) contained, besides three plant forms, about 65 taxa of animals including ostracods $(\sim 3$ taxa), molluscs $(\sim 20)$, and undifferentiated lower vertebrates $(\sim 7)$ as well as mammals $(\sim 31)$. As scientific research progressed and with additional material added during the following years, the number of mollusc taxa grew to 51 species (Gall 1972) 

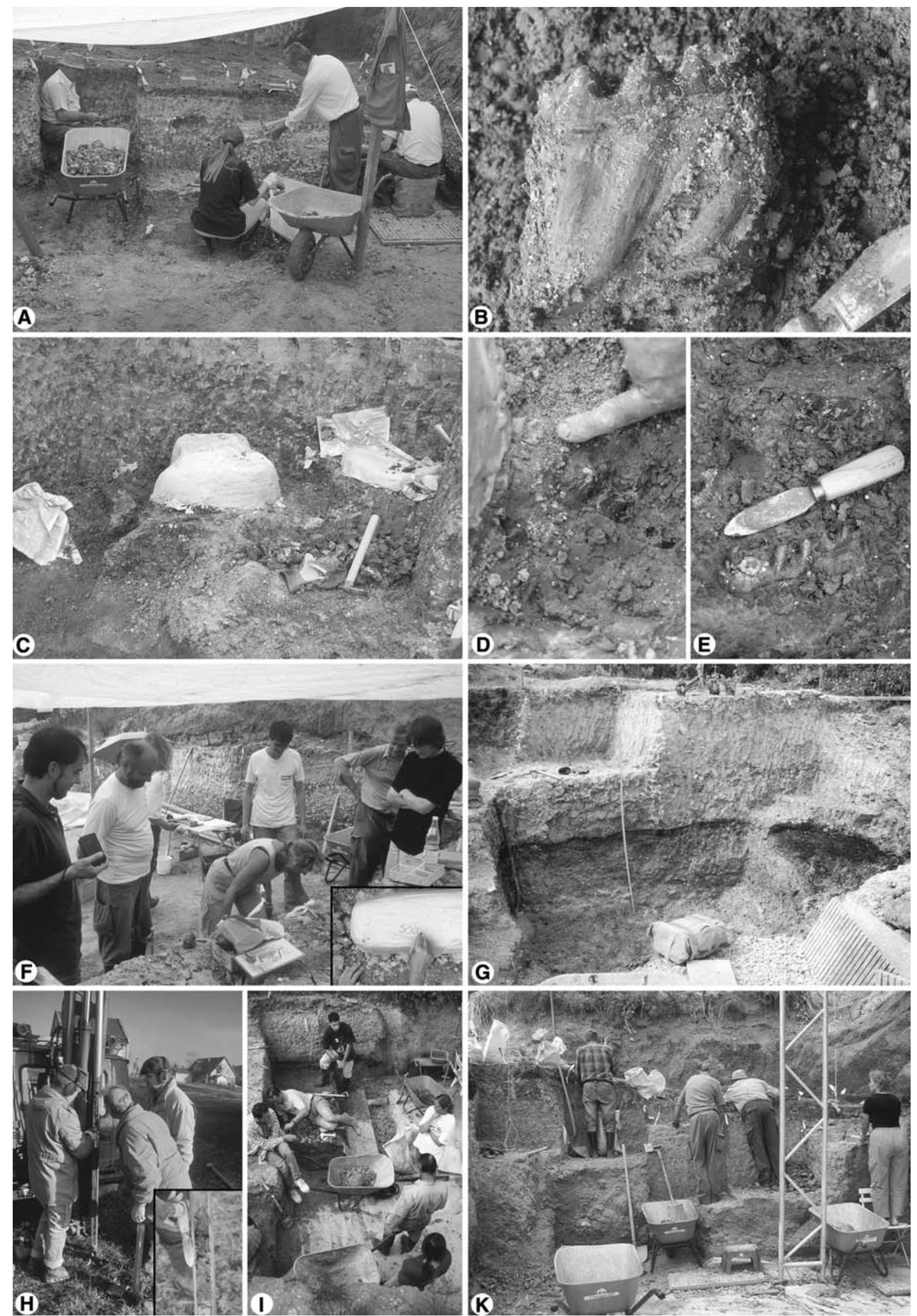
4 Fig. 4 Sandelzhausen field photos 1997-2001 (all photos by M.M.). a The fieldwork was conducted mostly with the help of volunteers, some of whom were active for several years, such as F. Reinfelder, N. Ballerstaedt, H. Hinle, and J. Herrlen (left to right, 1997). b Rewarding finds: well-preserved molar of Gomphotherium subtapiroideum (1997). c-e In a line just a few meters off the eastern border of the fossil site, a higher concentration of fossils was observed. Sometimes, plaster near plaster had to be made, and the next fossils were encountered even before the plasters could be removed (lower jaws of a juvenile Gomphotherium in c, close-ups of later excavation stages d, e; 1997). f R. Liebreich measuring length and position of a Gomphotherium tusk. Inset: plaster package number 5,000. More than 6,000 larger fossils and plaster packages were recovered up to the end of the campaign in 2001 (picture 1997). g Old site west of the Prof.Dehm-Straße, with well-exposed layers $A-D$. The weakly coalified "coal-layer" is visible as dark band in the middle of the profile (1997). h With the mobile drilling equipment of the Bayerisches Geologisches Landesamt (Bavarian Geological Survey, now part of the Bayerisches Landesamt für Umwelt) ten cores (e.g., inset figure) were taken to find the extent of the fossiliferous layer towards the north and east of the new digging site (January 1998). i For the University of Munich, 1 week each year was reserved for geology students for an educational digging course. Twice, digging courses were also arranged for students from Mainz and Vienna (this picture, 2000). $\mathbf{k}$ The high layers $E-F$ are exposed here on the left (southern) side. Selected material was put into sacks for screen washing (2001)

and that for mammals to 57 species (Fahlbusch et al. 1974). Summarizing results of the first continuous digging period (1969-1975), Fahlbusch (1976b) thus estimated the fauna contained in the site to be clearly in excess of 100 species. After the second digging period (1994-2001) and additional investigations by specialists, Fahlbusch (2003) was able to list $185+$ taxa from Sandelzhausen, thus documenting the exceptional richness of this fossil lagerstätte (see Table 1 for details). Regarding the future potential of the site, it is noteworthy that even in most recent years every digging season resulted in the addition of new taxa. We thus conclude that further digging would still add significantly to our knowledge of rare species, complete our knowledge of the general morphology and variability of known species, as well as augment our detailed knowledge of the palaeoecology, environment, and genesis of the site. A summary of the fossil content listing taxon numbers and key references is presented in Table 1.

In comparison with other localities in the OSM, the socalled lagerstätten effect known from other fossil-rich localities (Messel, Solnhofen, Burgess Shale, etc.) has recently been recognized for Sandelzhausen: earlier investigations indicated that the faunas older than $\sim 15 \mathrm{Ma}$ (including Sandelzhausen) seemed to be richer, especially in the ecologically demanding ectothermic vertebrates, than the immediately subsequent species-poor faunas. This had been attributed to a catastrophic regional extinction during the Ries impact event (Schleich 1985). However, this pattern is now known to be the result of the smaller fossil sample sizes recovered from all localities except
Sandelzhausen, partly amended in recent years (Heissig 1986; Böhme et al. 2002).

\section{Age of the Sandelzhausen fossil site (Fig. 6)}

In earlier publications, the age of Sandelzhausen had been cited as Upper Miocene (e.g., Fahlbusch and Gall 1970; Fahlbusch et al. 1974; Fahlbusch 1977). A shift in Tethyan-Paratethyan marine correlations as well as continental-marine correlations (Fahlbusch 1976a, 1981) resulted in a new age estimate as old as the (middle) Middle Miocene for Sandelzhausen (cited, e.g., by Schleich 1983; Heissig 1989a, b). Finally, based on a change in mammal biochronological correlation (Heissig 1997), Sandelzhausen is now regarded as close to the Lower/ Middle Miocene boundary in age (see below).

\section{Lithostratigraphy}

The regional lithostratigraphical setting was recently reinvestigated by Abdul Aziz et al. (2008: Fig. 2). According to regional mapping and lithostratigraphic correlations, the Sandelzhausen section belongs to the upper part of the Nördlicher Vollschotter lithostratigraphic unit. This upper part can be subdivided by the 7-m-thick Zwischenmergel into two members and Sandelzhausen belongs to the lower one. Within this up to 35-m-thick member, the fossil locality is situated near the top and can thus lithostratigraphically correlated to other nearby fossil localities such as Gisseltshausen $1 b$, Unterempfenbach $1 b+1 d$, Puttenhausen $\mathrm{E}$, and Maßendorf (the latter might be only slightly older).

\section{Biochronology}

Initially, the age of the Sandelzhausen locality was biostratigraphically dated as belonging to the regional "Mittlere Serie" of the OSM, a subdivision proposed using proboscideans as index fossils (Dehm 1951, 1955; Fahlbusch and Gall 1970). According to Dehm (1955), the "Mittlere Serie" is thus characterized by the presence of Gomphotherium angustidens and "Deinotherium" bavaricum; the lack in Sandelzhausen of the latter species was initially attributed to the then incompletely known fossil record of the site (Fahlbusch and Gall 1970). However, Deinotherium (actually Prodeinotherium) fossils have never been encountered in Sandelzhausen (Schmidt-Kittler 1972; Göhlich 1999, 2009), therefore the site must be assigned to the "Ältere Serie" of the Bavarian OSM, from which Prodeinotherium, an African immigrant to Europe during the Lower Miocene (Tassy 1989; Antunes 1989), is unknown regionally, possibly for ecological reasons. 


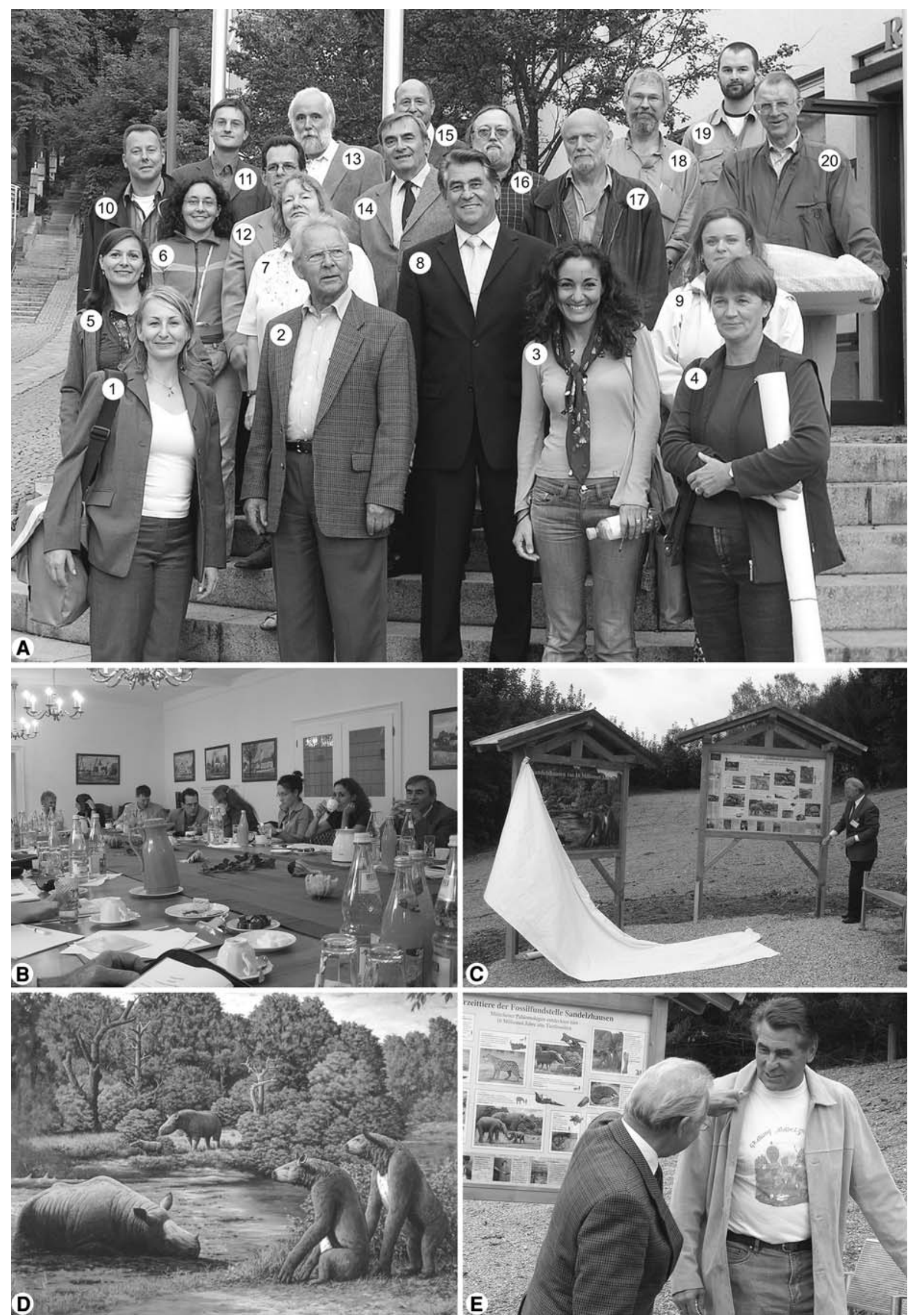


4 Fig. 5 The Sandelzhausen Meeting 2005 in Mainburg (all photos by M.M.). a Participants of the Sandelzhausen meeting: 1 Gertrud E. Rössner (Munich), 2 Volker Fahlbusch (Munich), 3 Daria Petruso (Palermo, Italy), 4 Wilma Wessels (Utrecht, The Netherlands), 5 Ursula B. Göhlich (Munich, now Vienna, Austria), 6 Chiara Angelone (Roma, Italy), 7 Margery C. Coombs (Amherst, Massachusetts, USA), 8 Josef Egger (Mayor of Mainburg), 9 Henriette Jechorek (Görlitz), 10 Thorsten Kowalke (Munich), 11 Dietmar Jung (Munich), 12 Reinhard Ziegler (Stuttgart), 13 Gerhard Doppler (Munich), 14 Wolfgang Witt (Gündlkofen), 15 Pierre Mein (Lyon), 16 John Damuth (Santa Barbara, CA, USA), 17 Norbert Schmidt-Kittler (Mainz), 18 Jan van der Made (Madrid, Spain), 19 Ralph Annau (Munich), and 20 Kurt Heissig (Munich). Participants not shown in the picture: Madelaine Böhme (Munich), Hans Hinle (Kelheim), Thomas Kaiser (Hamburg), Markus Moser (Munich), Doris Nagel (Vienna), Jerome Prieto (Munich), Bettina Reichenbacher (Munich), Zbigniew Szyndlar (Krakow), and Clara Stefen (Dresden). b During session in the City Hall of Mainburg. c Opening ceremony of the information panels at the filled-in Sandelzhausen pit. d Reconstruction of the landscape of Sandelzhausen 16 million years ago by artist Wenzel Balat. Shown are the rhinos Plesiaceratherium (foreground) and Lartetotherium (background), and the chalicothere Metaschizotherium (right, with hind legs that are too short; M. Coombs, oral communication, at symposium 2005). The painting is also shown on the left panel in Fig. 4c. e Volker Fahlbusch with Josef Egger, first Mayor of Mainburg and generous supporter of the field campaigns of 1994-2001 and the meeting in 2005, with his Sandelzhausen digging shirt (cartoon painting by Bettina Schenk, formerly Munich, now Vienna)

The first investigations on mammals and gastropods from Sandelzhausen (Fahlbusch 1964; Fahlbusch et al. 1974; Gall 1972) refined the age determination as being contemporaneous either with Sansan (based on mammals, Fahlbusch et al. 1974; Heissig 1989b), which later became the reference locality for the European Neogene Land Mammal Zone/Age/Reference-Fauna MN6 (Mein 1975, 1989, 1999; Bruijn et al. 1992), or even Steinheim ("Silvana-Schichten", based on gastropods; Fahlbusch and Gall 1970; Gall 1972), the later reference locality for MN7 (Mein, op. cit.). Successive advances in the biochronology of the "Ältere" and "Mittlere Serie" of the OSM in Bavaria (Heissig 1989a, b, 1997; Böhme et al. 2002) resulted in a regional subdivision of the OSM into biochronologically discernible units intermediate between MN4 and MN6, of which OSM C is represented by Sandelzhausen as standard fauna reference locality (Heissig 1997). Heissig correlated this unit to the middle (or even early) MN5 and a middle position within the "Ältere Serie" of Dehm (1955), using the evolutionary stages of the rodents Megacricetodon aff. bavaricus and Miodyromys aegercii and the last occurrence of Anomalomys minor (Heissig 1997, 2005). Later, Abdul Aziz et al. (2008) reinvestigated the local biozonation and concluded that the units OSM C and OSM D are not distinctive enough and should be unified into the unit OSM C + D. Mein (2009 this volume) further corroborates the $\mathrm{MN}$ correlation by the presence of the eomyid Keramidomys thaleri, which is known from MN5 localities in France, Switzerland, and Austria, and which is replaced by Keramidomys carpathicus in MN6. In conclusion, considering all biochronological evidence, the fauna of Sandelzhausen belongs to the early middle MN5.

Absolute age and correlation to standard time scales

A correlation to the standard geological time scale is possible by magnetostratigraphy and via cross-correlation of localities in France and Austria, which are intercalated into marine strata dated biostratigraphically as Burdigalian (La Romieu: MN4) and Langhian (Beaugency-Tavers, Pontlevoy-Thenay: MN5) as well as upper Karpatian (Obergänserndorf, Teiritzberg: old MN5) and lower Badenian (Mühlbach, Grund: young MN5) (Fig. 5) (Heissig 1997; Daxner-Höck 1998, 2003; Ćorić et al. 2004; Harzhauser et al. 2002, 2003).

Absolute ages for the OSM are derived from intercalated bentonites found in Bavaria and Switzerland and from debris related to the Ries impact event, which also forms a regionally important marker horizon ("Brockhorizont") in Bavaria (Bolliger 1994; Heissig 1997; Böhme et al. 2002; Abdul Aziz et al. 2008). In Bavaria, only the main bentonite (late part of OSM F) is dated so far with an Ar-Ar age of $14.55 \pm 0.19 \mathrm{Ma}$, and new measurements of Ries glasses (corresponding to the "Brockhorizont", base of OSM F) result in an age estimate of $14.88 \pm 0.11 \mathrm{Ma}$ (Abdul Aziz et al. 2008). However, according to magnetostratigraphical results of sections containing the Brockhorizont, this age may be-although within error-slightly too old (Abdul Aziz et al. 2008). Combining both methods, the age of the Ries impact can be estimated to $14.78 \pm 0.1 \mathrm{Ma}$. Thus, the biochronostratigraphical units OSM E-F of Heissig (1997, updated by Böhme et al. 2002), can be correlated independently to the Langhian stage (Middle Miocene) (Fig. 6). For the older units OSM A (MN4) and B - C + D (MN5), no absolute ages are available yet from southern Germany, but unpublished Ar-Ar data of a bentonite within the upper part of OSM C + D indicate an age close to the BurdigalianLanghian boundary (in preparation). Absolute ages for MN4 faunas obtained in France, Poland, and Hungary have been recently published and summarized by Pálfy et al. (2007), resulting in age estimates for MN4 faunas ranging upwards to at least 17.0 Ma. Thus OSM units B, C + D are certainly bracketed by the absolute dates of 17.0 Ma and 15.3 Ma.

In Spain, large terrestrial sections including faunas belonging to the MN4 and MN5 zones have been repeatedly dated by means of magnetostratigraphical correlation (e.g., Sen 1997; Daams et al. 1998, 1999; Agustí et al. 2001; Larrasoaña et al. 2006; van Dam et al. 2006). The faunas, however, are biochronologically only roughly correlatable to the middle European faunas, due to the large geographical distance and faunal differences. Because of this, the several 


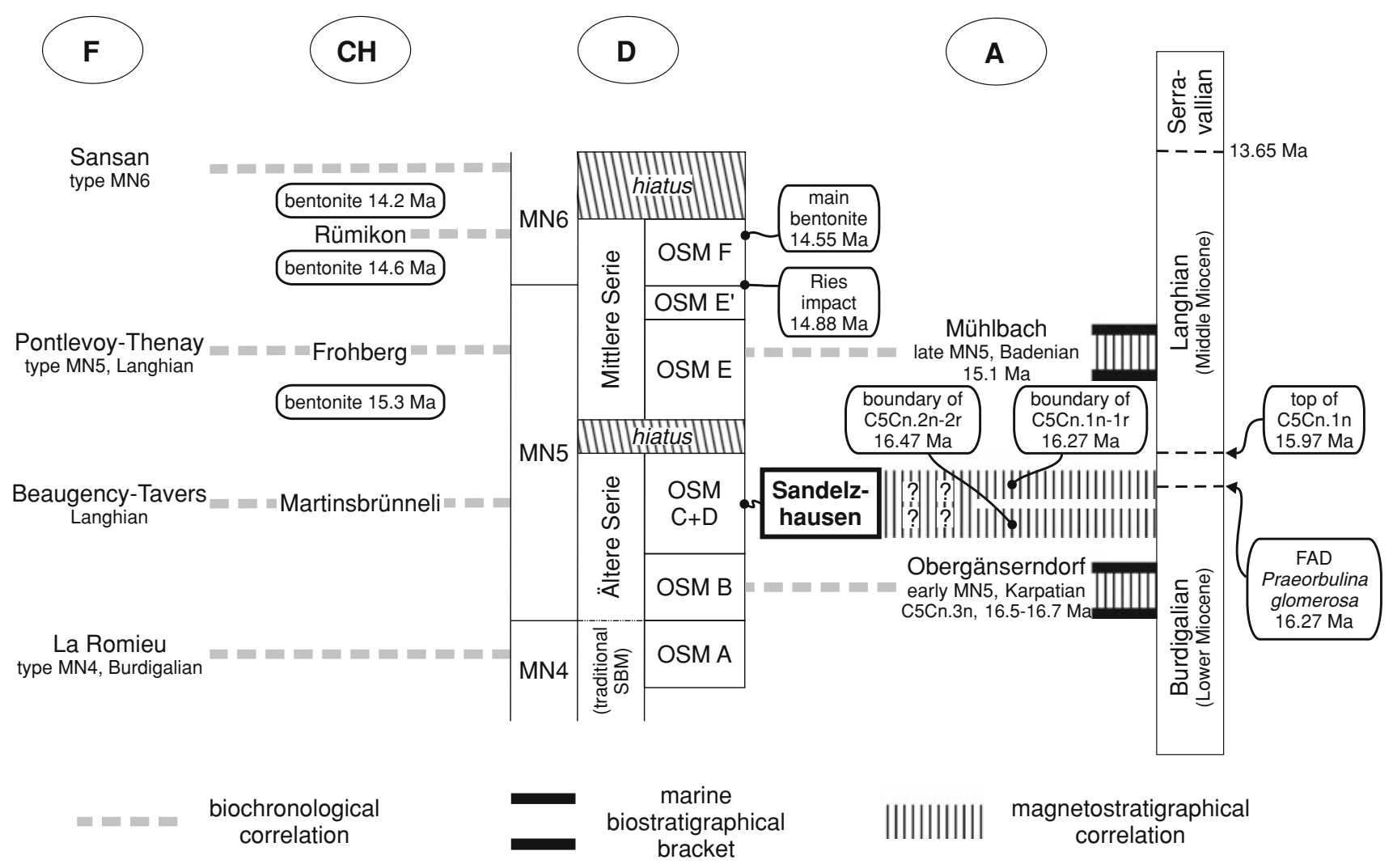

Fig. 6 Age of the Sandelzhausen fossil lagerstätte. A framework of biochronological, biostratigraphical, and magnetostratigraphical cross-correlations with localities in France $(F)$, Switzerland $(\mathrm{CH})$, and Austria $(A)$ allows dating of the localities of the Upper Freshwater Molasse (OSM) in Bavaria. Subdivision of OSM into series, and faunal units after Dehm (1951) and Heissig (1997), updated by Böhme et al. (2002) and Abdul Aziz et al. (2008). Absolute ages of bentonites in Switzerland after Bolliger (1994), new ages of main bentonite and Ries impact glasses in Bavaria after Abdul Aziz et al. (2008). Absolute dates for Austrian localities as reported by DaxnerHöck (2003) and Harzhauser et al. (2002, 2003). Absolute dates for

attempts to correlate terrestrial sections on a European scale with the continuous marine magnetostratigraphic scales are not conflict-free among themselves or compared with other correlation methods (see refs. above; for example, the Iberian faunas from Vargas and Fuente Sierra are attributed to MN4 and dated as young as 16.0 Ma, thus clearly postdating several MN5 localities in western and middle Europe).

Most recently, Abdul Aziz et al. (2008) provided magnetostratigraphic data for Sandelzhausen. Within the section, they identified an inverse to normal reversal event and correlate it with the reversal between magnetochron C5Cn.2r-2n of the Astronomically Tuned Neogene Time Scale (ATNTS04), corresponding to an absolute age around 16.47 Ma (Lourens et al. 2004, p. 470). However, a correlation to $\mathrm{C} 5 \mathrm{Cn} .1 \mathrm{r}-1 \mathrm{n}(16.27 \mathrm{Ma})$ is possible too, and appears to be not unlikely, considering that the classical fauna of Puttenhausen (close to Sandelzhausen) (Wu 1982; the boundaries of the global marine stages (right column) after Lourens et al. (2004), the stippled lines indicate the provisional status of the proposed boundaries (see text for details). Attribution of faunas to Mammal Neogen divisions (MN) after Heissig (1997) and DaxnerHöck (1998, 2003). Sandelzhausen belongs to (early) middle MN5 and can be correlated to either magnetochronological reversals $\mathrm{C} 5 \mathrm{Cn} .1 \mathrm{r}-1 \mathrm{n}$ or $\mathrm{C} 5 \mathrm{Cn} .2 \mathrm{r}-2 \mathrm{n}$ and to either the topmost Burdigalian (Lower Miocene) or the lowermost Langhian (Middle Miocene) stages of the global time scale. Accordingly, the absolute age can be given as 16.47 or $16.27 \mathrm{Ma}$

Heissig 1997; Abdul Aziz et al. 2008) is biochronologically and lithostratigraphically slightly older than Sandelzhausen (both belong to the late part of OSM C $+\mathrm{D}$ ), but cannot be older magnetostratigraphically than $\mathrm{C} 5 \mathrm{Cn} .2 \mathrm{r}$, as the fauna of Puttenhausen is biochronologically younger than that of Obergänserndorf (basal MN5; Austria; Daxner-Höck 1998), which belongs to magnetochron $\mathrm{C} 5 \mathrm{Cn} .3 \mathrm{n}$ and is bracketed well by marine biostratigraphy (Steininger 1999; Harzhauser et al. 2002).

Currently, no GSSP for the base of the Langhian stage (base of the Middle Miocene) has been defined, and differing concepts have been applied; traditionally, the base of the Langhian either is defined at the first appearance datum (FAD) of the planktonic foraminifer Praeorbulina glomerosa, which is almost coincident with the beginning of magnetochron $\mathrm{C} 5 \mathrm{Cn} .1 \mathrm{n}$ at $16.27 \mathrm{Ma}$, or at the FAD of Praeorbulina sicana, which in Mediterranean areas is 
about 16.3 or $16.4 \mathrm{Ma}$ in age (within magnetochron C5Cn.2n), but dated as old as $16.97 \mathrm{Ma}$ (amidst magnetochron C5Cr) in Atlantic cores (Berggren et al. 1995; Sprovieri et al. 2002; Ćorić et al. 2004; Lourens et al. 2004; Kováč et al. 2007). However, giving these uncertainties, Lourens et al. (2004) arbitrarily suggested setting the boundary at the top of $\mathrm{C} 5 \mathrm{Cn}$. $1 \mathrm{n}$ at $15.97 \mathrm{Ma}$ with no biostratigraphical background. Until this issue is settled (the ICS has scheduled a golden spike for 2008), it is therefore not possible to state whether Sandelzhausen is clearly Lower or Middle Miocene in age, but it is certainly very close to the boundary of these subseries. It may be noted here that several reptile taxa from Sandelzhausen such as Eoanilius (Szyndlar 2009 this volume), Palaeoblanus, Palaeocordylus, and Amblyolacerta (Böhme 2009), are typical for Late Oligocene and Early Miocene localities elsewhere.

In summary (Fig. 6), Sandelzhausen magnetostratigraphically correlates to either the C5Cn.1r-1n or the $2 \mathrm{r}-2 \mathrm{n}$ reversal event and biochronologically with either the topmost Burdigalian (Lower Miocene) or the basalmost Langhian (Middle Miocene) stages, corresponding in absolute ages to somewhat more than about $16 \mathrm{Ma}$.

Acknowledgments The investigation of the Sandelzhausen fossil site has been enthusiastically supported for over 40 years by a large number of individuals: students, scientists, neighbors and property owners, volunteers, and sponsors, among whom first we would like to name in most deserved gratitude our colleagues Winfried Werner and Renate Liebreich; then, Kurt Heissig, Norbert Schmidt-Kittler, as well as the volunteers Hans Hinle, Friedrich Reinfelder, Jörg Herrlen, and Dieter Dernbach for their long-lasting contribution to the fieldwork. We are indebted to the City of Mainburg (Mayor Josef Egger, the City Council, and co-workers), which provided its property for excavation, water, power, and technical help on numerous occasions without which the exploitation of the fossil site would not have been possible. The City also generously hosted and organized the Sandelzhausen Symposium 2005. Financial support for the first digging period (1969-1975) and the Sandelzhausen symposium 2005 in Mainburg came from the Deutsche Forschungs-Gemeinschaft (DFG, GZ 4850/ 88/05). The second digging period (1994-2001) was made possible almost exclusively by generous sponsors: the Freunde der Bayerischen Staatssammlung für Paläontologie und historische Geologie (München), the Bayerische Akademie der Wissenschaften, the companies Wolf Klimatechnik (Mainburg), Deutsche Gleis- und Tiefbau (Berlin), Pinsker Druck und Medien (Mainburg), Bosch-SiemensHaushaltsgeräte (München), the financial institutes Raiffeisenbank Hallertau/Mainburg, Sparkasse Kelheim and Stadtsparkasse München, and many others. Additionally, technical and material support came from the companies Thyssen-RÖRO (München), Ziegelwerke Leipfinger und Bader (Puttenhausen), Volkswagen (Abteilung Nutzfahrzeuge, München), Elektrofirma Burger (Mainburg), and the IsarAmper-Werke (now E·on, München). Last, but not least, we would like to thank the neighbors of the digging site for their generous hospitality towards our crews during both digging periods. We cordially thank Renate Liebreich and Winfried Werner (both Munich) who kindly reviewed an earlier draft of this work, Gudrun Höck and Mathias Harzhauser (both Vienna) for their valuable improvements, and John Damuth (Santa Barbara, CA, USA) for the improvement of the English.

\section{References}

Abdul Aziz, H., M. Böhme, A. Rocholl, A. Zwing, J. Prieto, J.R. Wijbrans, K. Heissig, and V. Bachtadse. 2008. Integrated stratigraphy and $40 \mathrm{Ar} / 39 \mathrm{Ar}$ chronology of the early to middle Miocene upper freshwater Molasse in eastern Bavaria (Germany). International Journal of Earth Sciences (Geologische Rundschau) 97: 115-134.

Abusch-Siewert, S. 1983. Gebißmorphologische Untersuchungen an eurasiatischen Anchitherien (Equidae, Mammalia) unter besonderer Berücksichtigung der Fundstelle Sandelzhausen. Courier Forschungsinstitut Senckenberg 62: 1-361.

Agustí, J., L. Cabrera, M. Garcés, W. Krijgsman, O. Oms, and J.M. Parés. 2001. A calibrated mammal scale for the Neogene of Western Europe. State of the art. Earth-Science Reviews 52(4): 247-260.

Angelone, C. 2009. Lagomorphs from the Miocene of Sandelzhausen (southern Germany).In Fossil lagerstätte Sandelzhausen (Miocene, southern Germany): contributions to the fauna. Paläontologische Zeitschrift, eds. Rössner, G.E., and U.B. Göhlich, 83(1).

Anonymous 2005. Sandelzhausen Symposium 2005. Symposium on the Miocene Fossillagerstätte Sandelzhausen (Mainburg, Bavaria, Germany), 13th to 15th September in Mainburg, Program. p. 80 (unpublished abstract volume).

Antunes, M.T. 1989. The proboscideans data, age and paleogeography: evidence from the Miocene of Lisbon. In European Neogene mammal chronology, NATO ASI Series (A) eds. Lindsay, E.H., Fahlbusch, V., and P. Mein, 180: 253-262. New York: Plenum Press.

Berggren, W.A., F.J. Hilgen, C.G. Langereis, D.V. Kent, J.D. Obradovich, I. Raffi, M.E. Raymo, and N.J. Shackleton. 1995. Late Neogene chronology; new perspectives in high-resolution stratigraphy. Geological Society of America Bulletin 107(1): $1272-1287$.

Blissenbach, E. 1957. Die jungtertiären Grobschotterschüttungen im Osten des bayerischen Molassetroges. Beiheft des Geologischen Jahrbuchs 26: 9-48.

Böhme, M. 1999a. Doppelschleichen (Sauria, Amphisbaenidae) aus dem Untermiozän von Stubersheim 3 (Süddeutschland). Mitteilungen der Bayerischen Staatssammlung für Paläontologie und historische Geologie 39: 85-90.

Böhme, M. 1999b. Die miozäne Fossil-Lagerstätte Sandelzhausen. 16. Fisch- und Herpetofauna- Erste Ergebnisse. Neues Jahrbuch für Geologie und Paläontologie, Abhandlungen 214: 487-495.

Böhme, M. 2003. The Miocene Climatic Optimum: evidence from ectothermic vertebrates of Central Europe. Palaeogeography, Palaeoclimatology, Palaeoecology 195(3-4): 389-401.

Böhme, M. 2009. Ectothermic vertebrates (Actinopterygii, Allocaudata, Urodela, Anura, Crocodylia, Squamata) from the Miocene of Sandelzhausen (Germany, Bavaria): their implication for environment reconstruction and palaeoclimate. Paläontologische Zeitschrift (accepted).

Böhme, M., A.A. Bruch, and A. Selmeier. 2007. The reconstruction of early and middle Miocene climate and vegetation in southern Germany as determined from the fossil wood flora. Palaeogeography, Palaeoclimatology, Palaeoecology 253(1-2): 107-130.

Böhme, M., H.-J. Gregor, and K. Heissig. 2002. The Ries and Steinheim meteorite impacts and their effect on environmental conditions in time and space. In Geological and biological effects of impact events, ed. E. Buffetaut, and C. Koeberl, 217235. Heidelberg: Springer.

Böhme, M., and B. Reichenbacher. 2003. Teleost fishes from the Karpatian (lower Miocene) of the western paratethys. In The Karpatian - an early Miocene stage of the central paratethys, 
ed. R. Brzobohaty, I. Cicha, M. Kovac, and F. Rögl, 23-45. Brno: Masaryk University.

Bolliger, T. 1994. Die Obere Süßwassermolasse in Bayern und der Ostschweiz: bio- und lithostratigraphische Korrelationen. Mitteilungen der Bayerischen Staatssammlung für Paläontologie und historische Geologie 34: 109-144.

Bruijn H. de. 2009. The Eumyarion (Mammalia, Rodentia, Muridae) assemblage from Sandelzhausen (Miocene, southern Germany), a test on homogeneity. In Fossil lagerstätte Sandelzhausen (Miocene, southern Germany): contributions to the fauna. Paläontologische Zeitschrift, eds. Rössner, G.E., and U.B. Göhlich, 83(1).

Bruijn H. de, Daams R., Daxner-Höck G., Fahlbusch V., Ginsburg L., Mein P. and J. Morales, 1992. Report of the RCMNS working group on fossil mammals, Reisensburg 1990. Newsletters on stratigraphy 26(2/3): $65-118$.

Calandra, I., U.B. Göhlich, and G. Merceron. 2009. Feeding preferences of Gomphotherium subtapiroideum (Mammalia, Proboscidea) from Sandelzhausen (Miocene, Molasse Basin, Germany) through life- and geological time: evidence from dental microwear analysis. Paläontologische Zeitschrift (accepted).

Coombs, M. 2009. The chalicothere Metaschizotherium bavaricum (Perissodactyla, Chalicotheriidae, Schizotheriinae) from the Miocene (MN5) Lagerstätte of Sandelzhausen (Germany): description, comparison, and paleoecological significance. In Fossil lagerstätte Sandelzhausen (Miocene, southern Germany): contributions to the fauna. Paläontologische Zeitschrift, eds. Rössner, G.E., and U.B. Göhlich, 83(1).

Ćorić, S., M. Harzhauser, J. Hohenegger, O. Mandic, P. Pervesler, R. Roetzel, F. Rögl, R. Scholger, S. Spezzaferii, K. Stingl, L. Švábenická, I. Zorn, and M. Zuschin. 2004. Stratigraphy and correlation of the grund formation in the Molasse basin, northeastern Austria (Middle Miocene, Lower Badenian). Geologica Carpathica 55(2): 207-215.

Daams, R., L. Alcalá, M.A. Alvarez Sierra, B. Azanza, J.A. van Dam, A.J. van der Meulen, J. Morales, M. Nieto, P. Peláez-Campomanes, and D. Soria. 1998. A stratigraphical framework for Miocene (MN4-MN13) continental sediments of Central Spain. Comptes rendus de l'Académie des Sciences Série II Fascicule a Sciences de la Terre et des Planètes 327(9): 625-631.

Daams, R., A.J. van der Meulen, M.A. Alvarez Sierra, P. PeláezCampomanes, and W. Krijgsman. 1999. Aragonian stratigraphy reconsidered, and a re-evaluation of the Middle Miocene mammal biochronology in Europe. Earth and Planetary Science Letters 165(3-4): 287-294.

van Dam, J.A., H. Abdul Aziz, M.Á. Álvarez Sierra, F.J. Hilgen, L.W. k Ostende, L.J. Lourens, P. Mein, A.J. van der Meulen, and P. Pelaez-Campomanes. 2006. Long-period astronomical forcing of mammal turnover. Nature 443(7112): 687-691.

Daxner-Höck, G. 1998. Säugetiere (Mammalia) aus dem Karpat des Korneuburger Beckens. 1. Rodentia und Carnivora. Beiträge zur Paläontologie 23: 367-407.

Daxner-Höck, G. 2003. Cricetodon meini and other rodents from Mühlbach and Grund, Lower Austria (Middle Miocene, late MN5). In Middle Miocene vertebrates from the Austrian Molasse Basin - tie points for marine/continental correlation. Annalen des Naturhistorischen Museums in Wien, ed. DaxnerHöck, G., ed. 104 A: 267-291.

Dehm, R. 1951. Zur Gliederung der Jungtertiären Molasse in Süddeutschland nach Säugetieren. Neues Jahrbuch Geologie Paläontologie, Monatshefte 1951: 140-152.

Dehm, R. 1955. Die Säugetierfaunen in der Oberen Süßwassermolasse und ihre Bedeutung für die Gliederung. Erläuterungen zur Geologischen Übersichtskarte der Süddeutschen Molasse 1:300 000: 81-88, München (Bayerisches Geologisches Landesamt).
Doppler, G. 1989. Zur Stratigraphie der nördlichen Vorlandmolasse in Bayerisch-Schwaben. Geologica Bavarica 94: 83-133.

Doppler, G., T. Pürner, and M. Seidel. 2000. Zur Gliederung und Kartierung der bayerischen Vorlandmolasse. Geologica Bavarica 105: 217-241.

Eronen, J.T., and G.E. Rössner. 2007. Wetland paradise lost: Miocene community dynamics in large herbivorous mammals from the German Molasse Basin. Evolutionary Ecology Research 9(3): 471-494.

Fahlbusch, V. 1964. Die Cricetiden (Mammalia) der Oberen Süßwassermolasse Bayerns. Abhandlungen der Bayerischen Akademie der Wissenschaften 118: 1-136.

Fahlbusch, V. 1975. Die Eomyiden (Rodentia, Mammalia) der Oberen Süßwassermolasse Bayerns. Mitteilungen der Bayerischen Staatssammlung für Paläontologie und historische Geologie 15: 63-90.

Fahlbusch, V. 1976a. Report on the international symposium on mammalian stratigraphy of the European Tertiary. Newsletter on Stratigraphy 5(2-3): 160-167.

Fahlbusch, V. 1976b. Die obermiozäne Wirbeltierfundstelle Sandelzhausen. Zentralblatt für Geologie und Paläontologie, (II) 1976(5-6): 255-261.

Fahlbusch, V. 1977. Die obermiozäne Fossil-Lagerstätte Sandelzhausen. 11. Ein neues Zwerghirsch-Geweih: Lagomeryx pumilio. Mitteilungen der Bayerischen Staatssammlung für Paläontologie und historische Geologie 17: 227-233.

Fahlbusch, V. 1981. Miozän und Pliozän-was ist was? Zur Gliederung des Jungtertiärs in Süddeutschland. Mitteilungen der Bayerischen Staatssammlung für Paläontologie und historische Geologie 21: 121-127.

Fahlbusch, V. 1998. Die miozäne Fossil-Lagerstätte Sandelzhausen. 15. Jüngster Nachweis des Schuppentieres Necromanis (Pholidota, Mammalia) in Deutschland. Mitteilungen der Bayerischen Staatssammlung für Paläontologie und historische Geologie 38: 183-186.

Fahlbusch, V. 2003. Die miozäne Fossil-Lagerstätte Sandelzhausen. Die Ausgrabungen 1994-2001. Zitteliana A 43: 109-122.

Fahlbusch, V., and H. Gall. 1970. Die obermiozäne Fossil-Lagerstätte Sandelzhausen. 1. Entdeckung, Geologie, Faunenübersicht und Grabungsbericht für 1969. Mitteilungen der Bayerischen Staatssammlung für Paläontologie und historische Geologie 10: 365396.

Fahlbusch, V., H. Gall, and N. Schmidt-Kittler. 1972. Die obermiozäne Fossil-Lagerstätte Sandelzhausen. 2. Sediment und FossilinhaltProbleme der Genese und Ökologie. Neues Jahrbuch für Geologie und Paläontologie, Monatshefte 1972: 331-343.

Fahlbusch, V., H. Gall, and N. Schmidt-Kittler. 1974. Die obermiozäne Fossil-Lagerstätte Sandelzhausen. 10. Die Grabungen 1970-1973 Beiträge zur Sedimentologie und Fauna. Mitteilungen der Bayerischen Staatssammlung für Paläontologie und historische Geologie 14: 103-128.

Fahlbusch, V., and R. Liebreich. 1996. Hasenhirsch und Hundebär . Chronik der tertiären Fossillagerstätte Sandelzhausen bei Mainburg, 40. München: F. Pfeil.

Gall, H. 1972. Die obermiozäne Fossil-Lagerstätte Sandelzhausen. 4. Die Molluskenfauna (Lamellibranchiata, Gastropoda) und ihre stratigraphische und ökologische Bedeutung. Mitteilungen der Bayerischen Staatssammlung für Paläontologie und historische Geologie 12: 3-32.

Gall, H. 1973. Die obermiozäne Fossil-Lagerstätte Sandelzhausen. 8. Konkretionäre Aufblähung von Gastropodengehäusen. Mitteilungen der Bayerischen Staatssammlung für Paläontologie und historische Geologie 13: 3-18.

Gentry, A.W., G. Rössner, and E.P.J. Heizmann. 1999. Suborder Ruminantia. In The Miocene land mammals of Europe, ed. G.E. Rössner, and K. Heissig, 225-258. München: F. Pfeil. 
Göhlich, U.B. 1998. Elephantoidea (Proboscidea, Mammalia) aus dem Mittel- und Obermiozän der Oberen Süßwassermolasse Süddeutschlands: Odontologie und Osteologie. Münchner Geowissenschaftliche Abhandlungen (A) 36: 1-245, München: F. Pfeil.

Göhlich, U.B. 1999. Order Proboscidea. In The Miocene land mammals of Europe, ed. G.E. Rössner, and K. Heissig, 157168. München: F. Pfeil.

Göhlich, U.B. 2002. The avifauna of the Miocene Fossillagerstätte Sandelzhausen (upper freshwater molasse, southern Germany). Zitteliana 22: 169-190.

Göhlich, U.B. 2003. A new crane (Aves, Gruidae) from the Middle Miocene of Sandelzhausen (Upper Freshwater Molasse, southern Germany). Journal of Vertebrate Paleontology 23(2): 387-393.

Göhlich, U.B. 2009. The Miocene proboscidean fauna (mammalia) from Sandelzhausen, southern Germany. Paläontologische Zeitschrift (accepted).

Gregor, H.J. 1982a. Die Jungtertiären Floren Süddeutschlands. Paläokarpologie, Phytostratigraphie, Paläoökologie, Paläoklimatologie, p.278. Stuttgart: Enke.

Gregor, H.J. 1982b. Zur Ökologie der jungtertiären SäugetierFundstelle Sandelzhausen. Documenta naturae 4: 19-26.

Gregor, H.J., M. Hottenrott, E. Knobloch, and E. Planderova. 1989. Neue mega- und mikrofloristische Untersuchungen in der jungtertiären Molasse Bayerns. Geologica Bavarica 94: 281-369.

Harzhauser, M., M. Böhme, O. Mandic, and Ch.-Ch. Hofmann. 2002. The Karpatian (Late Burdigalian) of the Korneuburg basin-a palaeoecological and biostratigraphical syntheses [sic]. Beiträge zur Paläontologie 27: 441-456.

Harzhauser, M., Daxner-Höck, G., Boon-Kristkoiz, E., Ćorić, S., Mandic, O., Miklas-Tempfer, P., Roetzel, R., Rögl, F., Schultz, O., Spezzaferri, S., Ziegler, R., and I. Zorn. 2003. Paleoecology and biostratigraphy of the section Mühlbach (Gaindorf Formation, Lower Middle Miocene, Lower Badenian, Austria). In Middle Miocene vertebrates from the Austrian Molasse Basintie points for marine/continental correlation, Annalen des Naturhistorischen Museums in Wien, ed. Daxner-Höck, G. 104 A: $323-334$

Heissig, K. 1972. Die obermiozäne Fossil-Lagerstätte Sandelzhausen. 5. Rhinocerotidae (Mammalia), Systematik und Ökologie. Mitteilungen der Bayerischen Staatssammlung für Paläontologie und historische Geologie 12: 57-81.

Heissig, K. 1986. No effect of the Ries impact event on the local mammal fauna. Modern Geology 10: 171-179.

Heissig, K. 1989a. The faunal succession in the Bavarian Molasse reconsidered - correlation of the MN5 and MN6 faunas. In European Neogene mammal chronology. NATO ASI Series, (A) Lindsay, E.H., Fahlbusch, V., and P. Mein, eds. 180: 181-192, New York: Plenum Press.

Heissig, K. 1989b. Neue Ergebnisse zur Stratigraphie der Mittleren Serie der Oberen Süßwassermolasse Bayerns. Geologica Bavarica 94: 239-257.

Heissig, K. 1997. Mammal faunas intermediate between the reference faunas of MN 4 and MN 6 from the Upper Freshwater Molasse of Bavaria. In Actes du Congrès BiochroM'97, Mémoires et Travaux de l'Ecole Pratique des Hautes Etudes, Institut de Montpellier, eds. Aguilar, J.-P., Legendre, S., and J. Michaux, 21: 537-546.

Heissig, K. 1999. Family Rhinocerotidae. In The Miocene land mammals of Europe, eds. Rössner, G.E., and K. Heissig, 175188. München: F. Pfeil.

Heissig, K. 2005. The stratigraphic position of the fossil site Sandelzhausen. In: Sandelzhausen Symposium 2005-symposium on the Miocene Fossillagerstätte Sandelzhausen (Mainburg, Bavaria, Germany), 13th to 15th September in Mainburg, Program ed. Anonymous, 36-37 (abstract).
Heissig, K. 2006. Die Gattung Miodyromys (Gliridae, Mammalia) im tiefen Mittelmiozän der Oberen Süßwassermolasse Bayerns. In Festschrift für Univ.-Doz. Dr. Gudrun Daxner-Höck gewidmet aus Anlass ihres 65. Geburtstages, Beiträge zur Paläontologie, eds. Hoek Ostende, L. W. van den, Nagel, D., and M. Harzhauser, 30: 143-153.

Herold, R., and A.H. Ibrahim. 1972. Die obermiozäne FossilLagerstätte Sandelzhausen. 7. Über die Einregelung der Fossilien. Mitteilungen der Bayerischen Staatssammlung für Paläontologie und historische Geologie 12: 125-135.

Hugueney, M. 1999. Family Castoridae. In The Miocene land mammals of Europe, ed. G.E. Rössner, and K. Heissig, 281300. München: F. Pfeil.

Jechorek, H. and Kovar-Eder, J. 2004. Vegetational Characteristics in Europe around the Late Early to Early Middle Miocene Based on the Plant Macro Record. In The Middle Miocene Environments and Ecosystem Dynamics of the Eurasian Neogene (EEDEN). Courier Forschungsinstitut Senckenberg, eds. Steininger, F. F., Kovar-Eder, J., and M. Fortelius, 249:53-62.

Jung, W. 1996. Die Pflanzenwelt zur Sandelzhausener Tertiärzeit. In Mineralientage München '96, Katalog der 33. Mineralientage München, ed. J. Keilmann, 173-181. München: R. Bode.

Kälin, D. 1999. Tribe Cricetini. In The Miocene land mammals of Europe, ed. G.E. Rössner, and K. Heissig, 373-387. München: F. Pfeil.

Kaiser, T.M., and G.E. Rössner. 2007. Dietary resource partitioning in ruminant communities of Miocene wetland and karst palaeoenvironments in southern Germany. Palaeogeography, Palaeoclimatology, Palaeoecology 252(3-4): 424-439.

Kaiser, T.M. 2009. Anchitherium aurelianense (Equidae, Mammalia) - a brachydont "dirty browser" in the community of herbivorous large mammals from Sandelzhausen (Miocene, Germany). In Fossil lagerstätte Sandelzhausen (Miocene, southern Germany): contributions to the fauna. Paläontologische Zeitschrift, eds. Rössner, G.E., and U.B. Göhlich, 83(1).

Köhler, M. 1993. Skeleton and Habitat of recent and fossil Ruminants. Münchner Geowissenschaftliche Abhandlungen, A 25: $1-88$.

von Koenigswald, W. 1999. Order Pholidota. In The Miocene land mammals of Europe, ed. G.E. Rössner, and K. Heissig, 75-80. München: F. Pfeil.

Kováč, M., A. Andreyeva-Grigorovich, Z. Bajraktarević, R. Brzobohatý, S. Filipescu, L. Fodor, M. Harzhauser, A. Nagymarosy, N. Oszczypko, D. Pavelić, F. Rögl, B. Saftić, U. Sliva, and B. Studencka. 2007. Badenian evolution of the Central Paratethys Sea: paleogeography, climate and eustatic sea-level changes. Geologica Carpathica 58(6): 579-606.

Larrasoaña, J.C., X. Murelaga, and M. Garcés. 2006. Magnetobiochronology of Lower Miocene (Ramblian) continental sediments from the Tudela formation (western Ebro basin, Spain). Earth and Planetary Science Letters 243(3-4): 409-423.

Lemcke, K. 1988. Geologie von Bayern-Das bayerische Alpenvorland vor der Eiszeit, vol. I, 175. Stuttgart: Schweizerbart.

Lemcke, K., W.v. Engelhardt, and H. Füchtbauer. 1953. Geologische und sedimentpetrographische Untersuchungen im Westteil der ungefalteten Molasse des süddeutschen Alpenvorlandes. Beiheft des Geologischen Jahrbuchs 11: 1-182.

Lourens, L.J., F.J. Hilgen, J. Laskar, N.J. Shackelton, and D. Wilson. 2004. The Neogene Period. In Geological Time Scale 2004, ed. F.M. Gradstein, J.G. Ogg, and A.G. Smith, 409-440. Cambridge: Cambridge University Press.

Made, J. van der 2009. The pigs and "Old World peccaries" (Suidae \& Palaeochoeridae, Suoidea, Artiodactyla) from the Middle Miocene of Sandelzhausen (southern Germany) — phylogeny and an updated classification of the Hyotheriinae and Palaeochoeridae. In Fossil lagerstätte Sandelzhausen (Miocene, southern 
Germany): contributions to the fauna. Paläontologische Zeitschrift, eds. Rössner, G.E., and U.B. Göhlich, 83(1).

Mayr, H. 1979. Gebißmorphologische Untersuchungen an miozänen Gliriden (Mammalia, Rodentia) Süddeutschlands. p. 380, unpublished PhD-Thesis, Universität München.

Mein, P. 1975. Résultats du groupe de travail des vertébrés: biozonation du Néogène méditerranéen à partir des mammifères. In Report on activity of the RCMNS working groups (19711975). 6. Congress of the Regional Committee of Mediterranean Neogene Stratigraphy Proceedings, ed. Senes, J., 1: 78-81, Bratislava: VEDA.

Mein, P. 1989. Updating of MN zones. In European Neogene mammal chronology, NATO ASI Series (A), eds. Lindsay, E.H., Fahlbusch, V., and P. Mein, 180: 73-90, New York: Plenum Press.

Mein, P. 1999. European Miocene mammal biochronology. In The Miocene land mammals of Euope, ed. G.E. Rössner, and K. Heissig, 25-38. München: F. Pfeil.

Mein, P. 2000. The Miocene Keramidomys (Rodentia, Eomyidae) from the Sandelzhausen locality (Germany). In Fossil lagerstätte Sandelzhausen (Miocene, southern Germany): contributions to the fauna. Paläontologische Zeitschrift, eds. Rössner, G.E., and U.B. Göhlich, 83(1).

Morlo, M., S. Peigné, and D. Nagel. 2004. A new species of Prosansanosmilus: implications for the systematic relationships of the family Barbourofelidae new rank (Carnivora, Mammalia). Zoological Journal of the Linnean Society 140(1): 43-61.

Moser, M., Niederhöfer, H.-J., and G. Falkner. 2009. Continental molluscs of the fossil site Sandelzhausen (Middle Miocene; Upper Freshwater Molasse from Bavaria) and their value for palaeoecological assessment. In Fossil lagerstätte Sandelzhausen (Miocene, southern Germany): contributions to the fauna. Paläontologische Zeitschrift, eds. Rössner, G.E., and U.B. Göhlich, 83(1).

Nagel, D., Stefen, C., and M. Morlo. 2009. The carnivoran community from the Miocene of Sandelzhausen (Germany). In Fossil lagerstätte Sandelzhausen (Miocene, southern Germany): contributions to the fauna. Paläontologische Zeitschrift, eds. Rössner, G.E., and U.B. Göhlich, 83(1).

Pálfy, J., R. Mundil, P.R. Renne, R.L. Bernor, L. Kordos, and M. Gasparik. 2007. U-Pb and ${ }^{40} \mathrm{Ar} /{ }^{39} \mathrm{Ar}$ dating of the Miocene fossil track site at Ipolytaróc (Hungary) and its implications. Earth and Planetary Science Letters 258(1-2): 160-174.

Peter, K. 1999. Sandelzhausen vor 16 Millionen Jahren: ein Dorado für Nashörner-Jahresbericht 1998 und Mitteilungen. Freunde der Bayerischen Staatssammlung für Paläontologie und historische Geologie München e.V. 27: 37-42.

Peter, K. 2002. Odontologie der Nashornverwandten (Rhinocerotidae) aus dem Miozän (MN 5) von Sandelzhausen (Bayern). Zitteliana 22: 3-168.

Reichenbacher, B., M. Böhme, K. Heissig, J. Prieto, and A. Kossler. 2004. New approach to assess biostratigraphy, palaeoecology and past climate in the South German Molasse Basin during the Early Miocene (Ottnangian, Karpatian). Courier Forschungsinstitut Senckenberg 249: 71-89.

Reichenbacher, B., and J. Prieto. 2006. Lacustrine fish faunas (Teleostei) from the Karpatian of the northern Alpine Molasse Basin, with a description of two new species of Prolebias Sauvage. Palaeontographica A 278(1-6): 87-95.

Riederle, R., and H.-J. Gregor. 1997. Die Tongrube Kirrberg bei Balzhausen-eine neue Fundstelle aus der Oberen Süßwassermolasse Bayerisch-Schwabens-Flora, Fauna, Stratigraphie. Documenta naturae 110: 1-53.

Rössner, G.E. 1997. Biochronology of ruminant assemblages in the Lower Miocene of southern Germany. In Actes du Congrès BiochroM'97, Mémoires et Travaux de l'Ecole Pratique des
Hautes Etudes, Institut de Montpellier, eds. Aguilar, J.-P., Legendre, S., and J. Michaux, 21: 609-618.

Rössner, G.E. 2002. Miozäne Ruminantia Süddeutschlands. Taxonomie und Ökologie. p. 160 (unpublished Habilitationsschrift, Department für Geo- und Umweltwissenschaften, Universität München).

Rössner, G.E. 2004. Community structure and regional patterns in late Early to Middle Miocene Ruminantia of Central Europe. In The Middle Miocene environments and ecosystem dynamics of the Eurasian Neogene (EEDEN), Courier Forschungsinstitut Senckenberg, eds. Steininger, F.F., Kovar-Eder, J., and M. Fortelius, 249: $91-100$.

Rössner, G.E. 2006a. Sandelzhausen Symposium 2005. GMIT 23: 101-103.

Rössner, G.E. 2006b. A community of Middle Miocene Ruminantia (Mammalian, Artiodactyla) from the German Molasse Basin. Palaeontographica A 278(1-6): 101-110.

Rössner, G.E. 2009. Systematics and palaeoecology of the Ruminantia (Artiodactyla, Mammalia) community from Sandelzhausen (Early/Middle Miocene) in the German Molasse Basin. Paläontologische Zeitschrift (accepted).

Rössner, G.E., and V. Fahlbusch. 2006. Sandelzhausen symposium 2005. Jahresbericht 2005 und Mitteilungen der Freunde der Bayerischen Staatssammlung für Paläontologie und historische Geologie München e.V. 34: 52-55.

Rummel, M. 1999. Tribe Cricetodontini. In The Miocene land mammals of Europe, ed. G.E. Rössner, and K. Heissig, 359-364. München: F. Pfeil.

Sach, V. 1999. Litho- und biostratigraphische Untersuchungen in der Oberen Süßwassermolasse des Landkreises Biberach a. d. Riß (Oberschwaben). Stuttgarter Beiträge zur Naturkunde B 276: 1167.

Sach, V., J. Gaudant, B. Reichenbacher, and M. Böhme. 2003. Die Fischfaunen der Fundstellen Edelbeuren-Maurerkopf und Wannenwaldtobel 2 (Miozän, Obere Süßwassermolasse, Süddeutschland). Stuttgarter Beiträge zur Naturkunde B 334: 1-25.

Scherer, E. 1973. Die obermiozäne Fossil-Lagerstätte Sandelzhausen. 9. Crocodilia. Mitteilungen der Bayerischen Staatssammlung für Paläontologie und historische Geologie 13: 103-114.

Scherer, E. 1981. Die mittelmiozäne Fossil-Lagerstätte Sandelzhausen. 12. Crocodylia (abschließender Bericht). Mitteilungen der Bayerischen Staatssammlung für Paläontologie und historische Geologie 21: 81-87.

Schleich, H.-H. 1981. Jungtertiäre Schildkröten Süddeutschlands unter besonderer Berücksichtigung der Fundstelle Sandelzhausen. Courier Forschungsinstitut Senckenberg 48: 1-372.

Schleich, H.-H. 1983. Die mittelmiozäne Fossil-Lagerstätte Sandelzhausen. 13. Chamaeleo bavaricus sp. nov., ein neuer Nachweis aus dem Jungtertiär Süddeutschlands. Mitteilungen der Bayerischen Staatssammlung für Paläontologie und historische Geologie 23: 77-81.

Schleich, H.-H. 1984. Neogene testudines of Germany · their stratigraphical and ecological evaluation. In Studia Palaeocheloniologica I, Studia Geologica Salmanticensia, eds. de Broin, F., and F. Jiménez-Fuentes, vol. especial 1: 249-267.

Schleich, H.-H. 1985. Zur Verbreitung tertiärer und quartärer Reptilien und Amphibien. Münchner Geowissenschaftliche Abhandlungen A 4: 67-149.

Schmid, W. 2002. Ablagerungsmilieu, Verwitterung und Paläoböden feinklastischer Sedimente der Oberen Süßwassermolasse Bayerns. Abhandlungen der Bayerischen Akademie der Wissenschaften, mathematisch-naturwissenschaftliche Klasse, Neue Folge 172: 207.

Schmid, W., and H.-J. Gregor. 1983. Gallenbach - eine neue mittelmiozäne Fossilfundstelle in der westlichen Oberen Süßwassermolasse Bayerns. Berichte des Naturwissenschaftlichen Vereins für Schwaben 8: 51-63. 
Schmidt, C. 1976. Obermiozäne Flora von Derching bei Augsburg. Berichte des Naturwissenschaftlichen Vereins für Schwaben e. V. 803(4): 53-56.

Schmidt, C. 1980. Ein Profil von pflanzenführenden Schichten der Sandgrube Derching. Berichte des Naturwissenschaftlichen Vereins für Schwaben e.V. 841(2): 13-15.

Schmidt-Kittler, N. 1971. Die obermiozäne Fossillagerstätte Sandelzhausen. 3. Suidae (Artiodactyla, Mammalia). Mitteilungen der Bayerischen Staatssammlung für Paläontologie und historische Geologie 11: 129-170.

Schmidt-Kittler, N. 1972. Die obermiozäne Fossil-Lagerstätte Sandelzhausen. 6. Proboscidea (Mammalia). Mitteilungen der Bayerischen Staatssammlung für Paläontologie und historische Geologie 12: 83-95.

Schulz, E., and J. Fahlke. 2009. The diet of Metaschizotherium bavaricum (Chalicotheriidae, Mammalia) from the MN 5 of Sandelzhausen (Germany) implied by the mesowear method. In Fossil lagerstätte Sandelzhausen (Miocene, southern Germany): contributions to the fauna. Paläontologische Zeitschrift, eds. Rössner, G.E., and U.B. Göhlich, 83(1).

Schwarz, J., and B. Reichenbacher. 1989. Die Charophytenflora der Kirchberger Schichten (Unter-Miozän). Geologica Bavarica 94: 179-193.

Schweigert, G. 1992. Die untermiozäne Flora (Karpatium, MN5) des Süßwasserkalkes von Engelswies bei Meßkirch (Baden-Württemberg). Stuttgarter Beiträge zur Naturkunde, Serie B 188: 155.

Schwerd, K., Doppler, G., and H-J. Unger. 1996. Gesteinsfolge des Molassebeckens und der inneralpinen Tertiärbecken, Kap. 4.1 Allgemeiner Überblick. In Erläuterungen zur Geologischen Karte von Bayern, ed. Bayerisches Geologisches Landesamt, 1: 500 000, 4. Aufl.: 141-149, München: Bayerisches Geologisches Landesamt.

Seehuber, U. 2002. Sedimentologische und paläontologische Untersuchungen in der Oberen Süßwassermolasse östlich Derching (Landkreis Aichach-Friedberg, Bayern). Neues Jahrbuch für Geologie und Paläontologie, Abhandlungen 223: 201-239.

Selmeier, A. 1989. Funde verkieselter Hölzer aus dem nordalpinen Molassebecken und einigen Randgebieten. Geologica Bavarica 94: 409-446.

Sen, S. 1997. Magnetostratigraphic calibration of the European Neogene mammal chronology. Palaeogeography, Palaeoclimatology, Palaeoecology 133(3-4): 181-204.

Spitzlberger, G. 1989. Die Miozänfundstelle Goldern bei Landshut (Niederbayern). Geologica Bavarica 94: 371-407.

Sprovieri, R., S. Bonomo, A. Caruso, A. Di Stefano, E. Di Stefano, L.M. Foresi, S. Iaccarino, F. Lirer, R. Mazzei, and G. Salvatorini. 2002. An Integrated calcareous plankton biostratigraphic scheme and biochronology of the Mediterranean Middle Miocene. Rivista Italiana di Paleontologia e Stratigraphia 108(2): 337-353.

Stefen, C. 2009. The beaver (Mammalia, Castoridae) from the Miocene of Sandelzhausen (southern Germany). In Fossil lagerstätte Sandelzhausen (Miocene, southern Germany): contributions to the fauna. Paläontologische Zeitschrift, eds. Rössner, G.E., and U.B. Göhlich, 83(1).

Steininger, F.F. 1999. Chronostratigraphy, geochronology and biochronology of the Miocene "European Land Mammal MegaZones" (ELMMZ) and the Miocene "Mammal-Zones (MNZones)". In The Miocene land mammals of Europe, ed. G.E. Rössner, and K. Heissig, 9-24. München: F. Pfeil.

Szyndlar, Z. 2009. Snake fauna (Reptilia: Serpentes) from the Early/ Middle Miocene of Sandelzhausen and Rothenstein 13 (Germany). In Fossil lagerstätte Sandelzhausen (Miocene, southern Germany): contributions to the fauna. Paläontologische Zeitschrift, eds. Rössner, G.E., and U.B. Göhlich, 83(1).

Tassy, P. 1989. The "Proboscidean datum event:" how many proboscideans and how many events? In European Neogene mammal chronology, NATO ASI Series, (A), eds. Lindsay, E.H., Fahlbusch, V., and P. Mein, 180: 237-252, New York: Plenum Press.

Tütken, T., and T. Vennemann. 2009. Stable isotope ecology of Miocene large mammals from Sandelzhausen, S Germany. In Fossil lagerstätte Sandelzhausen (Miocene, southern Germany): contributions to the fauna. Paläontologische Zeitschrift, eds. Rössner, G.E., and U.B. Göhlich, 83(1).

Unger, H.J. 1989. Die Lithozonen der Oberen Süßwassermolasse Südostbayerns und ihre vermutlichen zeitlichen Äquivalente gegen Westen und Osten. Geologica Bavarica 94: 195-237.

Wessels, W., and B.M. Reumer. 2009. Democricetodon and Megacricetodon (Mammalia, Cricetidae) from the Miocene of Sandelzhausen, southern Germany. In Fossil lagerstätte Sandelzhausen (Miocene, southern Germany): contributions to the fauna. Paläontologische Zeitschrift, eds. Rössner, G.E., and U.B. Göhlich, 83(1).

Witt, W. 1998. Die miozäne Fossil-Lagerstätte Sandelzhausen. 14. Ostracoden. Mitteilungen der Bayerischen Staatssammlung für Paläontologie und historische Geologie 38: 135-165.

Wu, W. 1982. Die Cricetiden (Mammalia, Rodentia) aus der Oberen Süßwassermolasse von Puttenhausen (Niederbayern). Zitteliana 9: 37-80.

Yan, D., and K. Heissig. 1986. Revision and autopodial morphology of the Chinese-European rhinocerotid genus Plesiaceratherium Young 1937. Zitteliana 14: 81-110.

Ziegler, R. 1999. Order Insectivora. In The Miocene land mammals of Europe, ed. G.E. Rössner, and K. Heissig, 53-74. München: F. Pfeil.

Ziegler, R. 2000. The Miocene Fossil-Lagerstätte Sandelzhausen, 17. Marsupialia, Lipotyphla and Chiroptera. Senckenbergiana lethaea 80: 81-127.

Ziegler, R. 2005. The squirrels (Sciuridae, Mammalia) of the Miocene Fossil-Lagerstaette Sandelzhausen (Bavaria, S Germany). Neues Jahrbuch für Geologie und Paläontologie, Abhandlungen 237(2): 273-312. 